\title{
Interactions of Organic Acids with Staphylococcus aureus and MRSA Strains from Swine Mandibular Lymph Node Tissue, Commercial Pork Sausage Meat and Feces
}

\author{
Ross Carlton Beier*, Kathleen Andrews, Toni Lee Poole, Roger Bruce Harvey, Tawni Lyn Crippen, \\ Robin Carl Anderson, David James Nisbet
}

United States Department of Agriculture, Agricultural Research Service, Southern Plains Agricultural Research Center, Food and Feed Safety Research Unit, College Station, Texas, United States of America

\section{Email address:}

ross.beier@usda.gov or ross.beier@yahoo.com (R. C. Beier), kate.andrews@usda.gov (K. Andrews), toni.poole@usda.gov (T. L. Poole), roger.harvey@usda.gov (R. B. Harvey), tc.crippen@usda.gov (T. L. Crippen), robin.anderson@usda.gov (R. C. Anderson),

david.nisbet@usda.gov (D. J. Nisbet)

${ }^{*}$ Corresponding author

\section{To cite this article:}

Ross Carlton Beier, Kathleen Andrews, Toni Lee Poole, Roger Bruce Harvey, Tawni Lyn Crippen, Robin Carl Anderson, David James Nisbet. Interactions of Organic Acids with Staphylococcus aureus and MRSA Strains from Swine Mandibular Lymph Node Tissue, Commercial Pork Sausage Meat and Feces. International Journal of Microbiology and Biotechnology. Vol. 5, No. 4, 2020, pp. 165-183. doi: $10.11648 /$ j.ijmb.20200504.12

Received: October 30, 2020; Accepted: November 11, 2020; Published: November 19, 2020

\begin{abstract}
Staphylococcus aureus is a Gram-positive bacterium affecting human health, and a major cause of skin infections, endocarditis, meningitis, and sepsis. Methicillin-resistant S. aureus (MRSA) is a worldwide health concern, occurs in food animals, is consistently found in swine, and improved strategies are needed to ensure the removal of MRSA from food products. A total of 164 S. aureus strains were isolated from swine mandibular lymph node tissue, commercial pork sausage meat, and feces. These strains were tested for methicillin-resistance, and 7 of the strains isolated from the mandibular lymph node tissue and pork sausage meat were resistant to cefoxitin and oxacillin, and tested positive for staph specific rRNA and for the $m e c A$ gene and are therefore, MRSA strains. An intracellular MRSA contamination of $8.2 \%$ within swine lymph node tissue and 5.8\% MRSA contamination in pork sausage meat was demonstrated. Lymph node tissue may be utilized in producing pork sausage; therefore, the prevalence of MRSA in final pork products may not only be caused by surface contamination, but by internal tissue infection. The strains were tested for susceptibility to six organic acids (OAs) citric, L-lactic, butyric, acetic, propionic, and formic acid. The $\mathrm{pH}$ was determined at each of the minimum inhibitory concentrations (MICs) observed for the S. aureus strains. The Henderson-Hasselbalch equation was used to calculate the ratio of the undissociated to dissociated OA concentrations, and the molar concentrations of each were calculated from the total OA present and the ratio. Inhibition of S. aureus did not correlate with $\mathrm{pH}$ or the undissociated OA concentrations, but it did correlate with the dissociated OA concentrations. A dissociated OA concentration of $21 \mathrm{mM}$ was successful for inhibiting the $S$. aureus strains tested. Studies must be conducted in vivo to confirm this concentration value. Acetic, butyric, formic, and propionic acid were the most effective OAs tested against S. aureus.
\end{abstract}

Keywords: Acetic Acid, Citric Acid, Formic Acid, L-Lactic Acid, Molar Minimum inhibitory Concentrations $\left(\mathrm{MIC}_{\mathrm{M}} \mathrm{s}\right)$, Organic Acids, Propionic Acid, Staphylococcus aureus, Susceptibility, Swine

\section{Introduction}

Staphylococcus aureus is a Gram-positive bacterium and one of the most important pathogens that affects human health [1, 2]. $S$. aureus is a major cause of both hospital and community acquired diseases of the skin, endocarditis, meningitis, and sepsis [3, 4], and is involved in the toxic shock syndrome $[5,6]$. The Centers for Disease Control (CDC) has recognized $S$. aureus as one of the top five germs that cause foodborne illness in the United States, and since it is commonly carried on the skin or in the nose of healthy people, when the situation is right $S$. aureus can cause infections in the blood stream and in major organs [7]. S. aureus can become 
resistant to the antibiotic methicillin, resulting in methicillin-resistant $S$. aureus (MRSA), and MRSA also may confer resistance to other common antibiotics like amoxicillin, oxacillin, and penicillin, rendering the MRSA isolate more difficult to treat $[8,9]$. Therefore, MRSA is regarded as a worldwide health concern [10]. There have been a number of reports worldwide of MRSA occurring in food animals since about 2004 [9-14].

$S$. aureus is known to commonly colonize pigs [9], and pig herds can be a reservoir for MRSA [10, 12, 13, 15]. MRSA is well known for being an important medical issue, and swine can be reservoirs for MRSA that can infect both swine workers and consumers through food products containing MRSA [16]. The prevalence of livestock-associated MRSA is known to be influenced by the use of disinfectants and feeding zinc $[17,18]$. Previous to 1995 , MRSA infections primarily occurred in hospitalized patients; however, since that time MRSA infections have been reported in non-hospitalized people [19]. S. aureus carriage in swine can result in occupational exposure, including exposure to antimicrobial resistant strains [19, 20]. In fact, occupational exposure to swine is a significant risk factor for contracting $S$. aureus infections [14, 21-25]. People with occupational exposure to swine production facilities may be up to six times more likely to be a carrier of MRSA than people without this exposure $[9,21]$. Workers may be exposed by direct contact with swine, or by airborne animal dander and decomposing waste $[20,26]$, and by aerosols as a result of the animals' normal activities [27]. These exposure risks may be enhanced by environmental dispersion of $S$. aureus and MRSA [28-30] and by leakage of stored waste or by applications of swine waste for crop fertilization [31-33]. Also, there is a doubling of the risk associated for contacting MRSA when a residential property is within 1 mile of a large swine feeding operation [15].

When pigs are colonized with $S$. aureus and MRSA and brought to the abattoir, they will bring that contamination to the abattoir and the processing plant [19]. Studies have shown that the prevalence of MRSA throughout different stages of processing from the carcass to the final cuts of meat show a decrease in MRSA along the process line $[34,35]$. The studies revealed that even with reductions in MRSA along the production line, a carriage of 11.3 to $64.7 \%$ measured at the point of stunning the animals results in a 2.2 to $6.6 \%$ prevalence of MRSA in the final product. The consumption of contaminated food causing MRSA colonization in humans has been observed [36, 37].

Developing new and improved strategies to control or eliminate foodborne pathogens in our food supply from farm-to-fork is a continuous research need required to help prevent illness from new or reemerging pathogens [38, 39]. In the United States, animal food processing plants utilize organic acids (OAs) to remove bacteria from the surfaces of hides and meats, and these treatments are simple, cost efficient, fast, and shown to have good efficacy [40]. Some of the OAs used are the following: propionic [41-43], lactic [41-49], formic [41], citric [43, 46], and acetic acid [41-43, 46, 48, 49], with lactic and acetic acid being the most often used $[48,49]$. The bacteria on a carcass not removed by the OA wash may later be found in the processed meat. Therefore, it is of importance to focus on improving the organic acid carcass wash step through a better understanding of the organic acid inhibition of bacteria.

Bacterial inhibition caused by OAs has been assumed by most researchers to be a result of the $\mathrm{pH}[50]$ or dependent on the undissociated form of the OAs [51-58]. However, to our knowledge there is no definitive study that shows that the undissociated form of the acid is the active OA species in the inhibition process, and the specific mechanism (s) causing bacterial inhibition by OAs are unknown [50, 59-61]. It has been demonstrated that the activities of OAs are altered with the level of $\mathrm{pH}$, the concentration of OA, and the type of OA used [59]. Also, it is known that the ability to utilize an OA as an energy source can drastically affect the bacterium's susceptibility to that OA [62]. Our previous studies with Gram-negative pathogenic bacteria [62-67] and a Gram-positive pathogenic bacterium [68] showed no correlation between the molar minimum inhibitory concentrations $\left(\mathrm{MIC}_{\mathrm{M}} \mathrm{s}\right)$ of the bacteria and the $\mathrm{pH}$ at the MICs or the undissociated OA levels at the MICs. The bacterial $\mathrm{MIC}_{\mathrm{M}} \mathrm{S}$ were correlated with the molar concentrations of the dissociated OAs. Molar MICs were used throughout the studies because using molarity demonstrated an accurate comparison of MICs with OAs having different molecular weights. Other researchers have shown that a dissociated OA can cause the disintegration of a bacterial LPS layer [69].

In this work we studied the inhibition interactions of $164 \mathrm{~S}$. aureus strains isolated from swine mandibular lymph node tissue, commercial pork sausage meat and feces against six organic acids. Studies to determine the susceptibility of these $S$. aureus isolates were conducted against the six OAs, citric, butyric, acetic, formic, L-lactic and propionic acid. The $\mathrm{pH}$ was determined at the MICs of the bacteria against each OA. Utilizing the determined $\mathrm{pH}$ for each bacteria-OA combination, the concentrations of both undissociated and dissociated OA species were calculated at the bacterial MICs.

\section{Materials and Methods}

\subsection{Staphylococcus aureus Strains}

S. aureus strains were isolated from 220 frozen 2017 swine mandibular lymph node tissue samples held at $-72^{\circ} \mathrm{C}(n=49$ strains), from 56 frozen 2019 blended commercial pork sausage meat samples held at $-72^{\circ} \mathrm{C}(n=52$ strains $)$ and from 266 frozen 2006 swine feces samples held at $-72^{\circ} \mathrm{C}(n=63$ strains) for a total of $164 \mathrm{~S}$. aureus strains. S. aureus cultures were grown for $24 \mathrm{~h}$ at $37^{\circ} \mathrm{C}$ on Trypticase Soy Agar w/5\% Sheep Blood (TSA II ${ }^{\mathrm{TM}}$ ) (BD BBL ${ }^{\mathrm{TM}}$ Stacker ${ }^{\mathrm{TM}}$ Plate, Becton, Dickinson and Company, Sparks, MD, USA).

\subsection{Chemicals and Materials}

Butyric, citric, formic and propionic acid came from Sigma-Aldrich (Milwaukee, WI, USA). Acetic acid was procured from EM Science (Gibbstown, NY, USA). L-Lactic acid was procured from Alfa Aesar (Ward Hill, MA, USA). Reverse osmosis water was produced on a reverse osmosis system (Millipore Corp., Bedford, MA, USA), and solutions of OAs were sterilized using $0.2 \times 25 \mathrm{~mm}$ syringe filters (No. 431224, Corning Inc., Corning, NY, USA). 


\subsection{Bacterial Culture and Isolation}

\subsubsection{Feces}

One-g of swine feces was added to 9-mL of $\mathrm{m}$ Staphylococcus Broth (BD Difco ${ }^{\mathrm{TM}}$, Becton, Dickinson and Company, Sparks, $\mathrm{MD}$, USA) and incubated at $37^{\circ} \mathrm{C}$ for $18-24 \mathrm{~h}$. Following incubation, a $10 \mu \mathrm{L}$ loop was used to streak the mixture onto CHROMagar ${ }^{\mathrm{TM}}$ Staph aureus Agar (CHROMagar, Paris France). The agar plates were incubated at $37^{\circ} \mathrm{C}$ for $18-24 \mathrm{~h}$. Typical mauve colored colonies were selected and re-streaked onto CHROMagar ${ }^{\mathrm{TM}}$ Staph aureus Agar and incubated at $37^{\circ} \mathrm{C}$ for 18-24 h. After incubation, those colonies were re-streaked onto BBL ${ }^{\text {TM }}$ Mannitol Salt Agar (Becton, Dickinson and Company) for secondary confirmation. Typical yellow colonies were selected and streaked onto TSA IITM and incubated at $37^{\circ} \mathrm{C}$ for 18-24 h. Hemolytic reactions were noted and identification testing was performed using ID 32 STAPH or RAPIDEC® Staph (bioMérieux, Inc, Durham, NC, USA). Confirmed S. aureus colonies were frozen in CryoCare ${ }^{\mathrm{TM}}$ Bacteria Preservers (Key Scientific Products, Inc, Stamford, TX, USA) until antibiotic and OA susceptibility testing were performed.

\subsubsection{Ground Pork Sausage}

Approximately 35 -g of ground pork meat was placed into a Whirl-Pak ${ }^{\circledR}$ filter bag (Nasco, Fort Atkinson, WI, USA) and 80-mL of $\mathrm{m}$ Staphylococcus Broth was added. The sample bags were homogenized for $30 \mathrm{~s}$ in a stomacher machine and then incubated at $37^{\circ} \mathrm{C}$ for $18-24 \mathrm{hr}$. A $10 \mu \mathrm{L}$ sample was removed and streaked onto CHROMagar ${ }^{\mathrm{TM}}$ Staph aureus Agar and further processed exactly as stated above for the feces samples.

\subsubsection{Swine Lymph Node and Tissue}

Approximately 30 -g of swine mandibular lymph node with the attached tissue was removed from the carcasses by hand, placed in a Whirl-Pak bag and frozen at $-72^{\circ} \mathrm{C}$ until further processing was performed. The lymph node/tissue was thawed at room temperature then surface sterilized by submersion in boiling water for 3 to $5 \mathrm{~s}$. After boiling, the lymph node/tissue was placed into a WHIRL-PAK $®$ filter bag and pulverized with a rubber mallet. Eighty-mL of $\mathrm{m}$ Staphylococcus Broth was added and processed as stated above for the ground pork meat.

\subsection{Determination of MRSA by Traditional Cefoxitin and Oxacillin Susceptibility Tests}

Frozen $S$. aureus isolates were plated onto TSA II ${ }^{\mathrm{TM}}$ agar and incubated at $37^{\circ} \mathrm{C}$ for $18-24 \mathrm{~h}$. Well-isolated colonies from the overnight plate were used to obtain a $0.5 \mathrm{McF}$ arland equivalent in $0.85 \%$ saline. Following the manufacturer's recommendations for Etest ${ }^{\circledR}$ (bioMérieux SA, Marcy-I'Étoile France), Mueller Hinton agar (MHA) was used as the medium for testing cefoxitin (FX), and $\mathrm{MHA}+2 \% \mathrm{NaCl}$ was used for testing oxacillin $(\mathrm{OX})$ Etest ${ }^{\circledR}$ gradient strips. The isolates on $\mathrm{MHA}$ and $\mathrm{MHA}+2 \% \mathrm{NaCl}$ were incubated at $35^{\circ} \mathrm{C}$ for $18-24$ $\mathrm{h}$ and $24 \mathrm{~h}$, respectively. An isolate was considered resistant at $>4 \mu \mathrm{g} / \mathrm{mL}$ and $\geq 4 \mu \mathrm{g} / \mathrm{mL}$ for FX and OX, respectively. Any isolate resistant to FX was subsequently tested with OX. The quality controls used were Staphylococcus aureus ATCC ( $29213^{\mathrm{TM}}$ and ATCC® $43300^{\mathrm{TM}}$.

\subsection{Determination of MRSA by Polymerase Chain Reaction (PCR) Methods}

Pure Staphylococcus isolates were plated and grown overnight on TSA with 5\% sheep blood (BVA Scientific, San Antonio, TX, USA), at $37^{\circ} \mathrm{C}$. The Staphylococcus DNA templates were obtained by heat treatment. Five colonies from an overnight incubated plate were suspended in $500 \mu \mathrm{L}$ of biotek water (Thermo Fisher Scientific, Carlsbad, CA, USA), and were heated to $100^{\circ} \mathrm{C}$ for $10 \mathrm{~min}$. This was followed by a brief centrifugation for $1 \mathrm{~min}$. at 5,000 rpm in an Eppendorf microfuge (Eppendorf North America, Enfield, CT, USA) as previously described [70].

Each $50 \mu \mathrm{L}$ PCR reaction mixture contained $5.0 \mu \mathrm{L}$ of a DNA template, $1 \mu \mathrm{L}$ of each primer (shown in Table 1) diluted to $10 \mathrm{pM}$ as stock [71], $25 \mu \mathrm{L}$ of Thermo Scientific Phusion high-Fidelity DNA polymerase master mix (Fisher Scientific, 300 Industry Dr., Pittsburgh, PA, USA), and $18 \mu \mathrm{L}$ of biotek water. The PCR reactions were run on an Eppendorf flexlid nexus gradient Mastercycler (Sigma-Aldrich, St. Louis, MO, USA).

All reactions were heated to $94^{\circ} \mathrm{C}$ for $1.0 \mathrm{~min}$., followed by 35 cycles of PCR with a denaturation temperature of $94^{\circ} \mathrm{C}(1.0$ min.), a primer annealing temperature of $55^{\circ} \mathrm{C}$ for $1.0 \mathrm{~min}$., and an extension temperature of $72^{\circ} \mathrm{C}$ for $1.0 \mathrm{~min}$. The final extension was at $72^{\circ} \mathrm{C}$ for $7 \mathrm{~min}$. Ten microliters of each PCR reaction mixture were combined with $6 \mathrm{X}$ loading buffer and loaded into a $1 \%$ agarose gel. The gel system was run at 100 volts using a Bio-Rad Powerpac 200 (Bio-Rad Laboratories, Hercules, CA, USA) for $2 \mathrm{hr}$. The gel was then visualized in an AlphaImager ${ }^{\circledR}$ HP gel imaging system from Alpha Innotech (San Leandro, CA, USA).

Table 1. Oligonucleotide sequences of PCR primers.

\begin{tabular}{lll}
\hline Gene & & Primers $^{\text {a }}$ \\
\hline clfA & $5^{\prime}$ & GCAAAATCCAGCACAACAGGAAACGA \\
& $3^{\prime}$ & CTTGATCTCCAGCCATAATTGGTGG \\
$m e c A$ & Length (bp) & 638 \\
& $5^{\prime}$ & TCCAGGAATGCAGAAAGACCAAAGC \\
& $3^{\prime}$ & GACACGATAGCCATCTTCATGTTGG \\
staphylococcal 16S rRNA & Length (bp) & 499 \\
& $5^{\prime}$ & CCTATAAGACTGGGATAACTTCGGG \\
& $3^{\prime}$ & CTTTGAGTTTCAACCTTGCGGTCG \\
\hline
\end{tabular}

a Primers for the genes $c l f A, m e c A$, and staphylococcal rRNA are from Mason et al. [71] and are written $5^{\prime}$ to $3^{\prime}$ as synthesized. 


\subsection{Bacterial Susceptibility Testing with Organic Acids}

The $S$. aureus MICs obtained against the six OAs, citric, butyric, acetic, L-lactic, propionic, and formic acid were determined using broth microdilution methods similar to those provided by the Clinical and Laboratory Standards Institute (CLSI) [72]. The MICs were determined to be the lowest concentration of an OA that resulted in no visible growth of $S$. aureus [73]. These susceptibility studies were conducted similarly to the susceptibility studies we carried out with other Gram-negative and Gram-positive pathogenic bacteria [63-66, 68]. Briefly, $50 \mu \mathrm{L}$ of Mueller-Hinton broth (Becton, Dickinson and Company, Sparks, MD, USA) was added to wells \#2 through \#12 of a 96-well U-bottom Greiner bio-one microplate (\#82050-626, VWR, Houston, TX, USA). The OA solutions $(50 \mu \mathrm{L})$ were then added to well \#1 and well \#2 of the microplate. The OA solution in well \#2 was diluted 1:2 across the microplate through well \#11, and well \#12 was used for the positive control [66]. S. aureus colonies were selected from TSA $I^{\mathrm{TM}}$ and transferred to a $5 \mathrm{~mL}$ Sensititre ${ }^{\circledR}$ demineralized water tube to mimic a $0.5 \mathrm{McF}$ arland standard using a Sensititre ${ }^{\circledR}$ Nephelometer ${ }^{\circledR}$ (Remel, Lenexa, KS, USA). Since each well of the 96 -well plate contains $50 \mu \mathrm{L}$ of an OA solution, $200-\mu \mathrm{L}$ of the $0.5 \mathrm{McF}$ arland $S$. aureus mixture was added to a tube containing $11 \mathrm{~mL}$ Mueller-Hinton broth w/TES (Remel, Lenexa, KS, USA) resulting in an inoculum of about $1 \times 10^{6} \mathrm{CFU} / \mathrm{mL}$ for each bacteria tested, and $50 \mu \mathrm{L}$ of this bacterial solution was added to each well in the 96 well microplate. Each plate was then covered with the adhesive film, SealPlate ${ }^{\circledR}$ (EXCEL Scientific, Inc., Victorville, CA, USA) and incubated for $20 \mathrm{~h}$ at $37^{\circ} \mathrm{C}$. Bacterial growth in the wells was determined by visual observation using a Sensititre ${ }^{\circledR}$ SensiTouch ${ }^{\circledR}$ (Remel, Lenexa, KS, USA). Staphylococcus aureus ATCC 29213 was the control organism used for OA susceptibility testing.

The OA concentrations evaluated were the following: citric acid, $32-32,768 \mu \mathrm{g} / \mathrm{mL}$; L-lactic acid, $32-32,768 \mu \mathrm{g} / \mathrm{mL}$; butyric acid, $32-32,768 \mu \mathrm{g} / \mathrm{mL}$; acetic acid, $32-32,768$ $\mu \mathrm{g} / \mathrm{mL}$; propionic acid, $32-32,768 \mu \mathrm{g} / \mathrm{mL}$; and formic acid, $16-16,384 \mu \mathrm{g} / \mathrm{mL}$.

\subsection{Determination of $\mathrm{pH}$ at the $\mathrm{S}$. aureus MICs Against the OAs Using a 96-well Microplate}

The $\mathrm{pH}$ was measured as described in a previous paper [66]. Briefly, the $\mathrm{pH}$ was measured in the wells of the 96-well microplate containing OA solutions at the $S$. aureus MICs against all OAs, in triplicate. Solutions from 16-wells (100 $\mu \mathrm{L} /$ well) were combined at each $S$. aureus MIC for all six OAs resulting in a total volume of $1600 \mu \mathrm{L}$ at each individual MIC and each combined set of wells per MIC were transferred to a $5 \mathrm{~mL}$ sterile microtube (Argos Technologies, Inc., Vernon Hills, IL, USA). A ROSS Ultra glass combination electrode with the Orion benchtop pH meter (Thermo Fisher Scientific, Chelmsford, MA, USA) was used to measure the $\mathrm{pH}$ of each microtube sample. The $\mathrm{pH}$ means and standard deviations were calculated and are shown in graphs presenting $\mathrm{pH}$ data.

\subsection{Calculation of the Ratios of the Undissociated to Dissociated OAs}

The Henderson-Hasselbalch equation can be used to calculate the ratio of the undissociated/dissociated OA concentration for a specific $\mathrm{OA}$ when the $\mathrm{pH}$ and $\mathrm{pK}_{\mathrm{a}}$ of the $\mathrm{OA}$ is known. The general Henderson-Hasselbalch equation is shown in (1) [74]:

$$
\mathrm{pH}=\mathrm{pK}_{\mathrm{a}}+\log \left(\left[\mathrm{A}^{-}\right] /[\mathrm{HA}]\right)
$$

where the $-\log _{10}$ of the specific OA dissociation constant $\left(\mathrm{K}_{\mathrm{a}}\right)=\mathrm{pK}_{\mathrm{a}}$, the molar concentration of the conjugate base (the dissociated $\mathrm{OA})=\left[\mathrm{A}^{-}\right]$, and the molar concentration of the undissociated $\mathrm{OA}=[\mathrm{HA}]$ [74]. When the equation is rearranged as shown in (2), it calculates the ratio of the undissociated to dissociated OA [63].

$$
\text { ratio }=[\mathrm{HA}] /\left[\mathrm{A}^{-}\right]=1 / 10^{\mathrm{pH}-\mathrm{pKa}}
$$

The ratio of each OA at the MICs was calculated given the use of published $\mathrm{pK}_{\mathrm{a}}$ 's for each $\mathrm{OA}$ and the measured $\mathrm{pH}$ at each of the MICs. The $\mathrm{pK}_{\mathrm{a}}$ for L-lactic, citric, butyric, acetic, propionic, and formic acid is $3.86,3.14,4.82,4.75,4.87$, and 3.75, respectively. Citric acid does have $3 \mathrm{pK}_{\mathrm{a}} \mathrm{s}, 3.14,4.77$, and 6.39; the first $\mathrm{pK}_{\mathrm{a}}=3.14$ was used for the calculations since this work is only concerned with the dissociation of any one $\mathrm{OH}$ group, it is not dependent on multiple $\mathrm{OH}$ groups. Since the molar concentrations of the OAs are exactly known at the MICs, then each calculated undissociated/dissociated OA ratio obtained from the Henderson-Hasselbalch equation at the $S$. aureus MICs will allow the calculation of the molar concentrations of the undissociated and dissociated OAs at the MICs [62-68].

\subsection{Statistics}

The central tendency was determined for the MICs and $\mathrm{MIC}_{\mathrm{M}}$ of the $164 \mathrm{~S}$. aureus strains against the $6 \mathrm{OAs}$ for all swine isolates. The central tendency also was determined for the MICs and $\mathrm{MIC}_{\mathrm{M}} \mathrm{S}$ of the $52 \mathrm{~S}$. aureus strains against the OAs isolated from only the pork sausage meat.

\section{Results}

\subsection{MRSA Strains Found in the 164 Strains Tested}

Seven strains $(4.3 \%)$ were determined to be MRSA out of the 164 total S. aureus strains collected in this study. Table 2 shows the number and percent of $S$. aureus and MRSA strains obtained from each swine source.

\subsection{Susceptibility Studies of S. aureus Strains Against Six OAs}

\subsubsection{Susceptibility Results for the Combined 164 S. aureus Strains}

The total MIC and $\mathrm{MIC}_{\mathrm{M}}$ data for the 164 S. aureus strains isolated from the 2006 swine feces, 2017 swine lymph node 
tissue, and 2019 pork sausage meat against six OAs are shown in Table 3. Citric acid and L-lactic acid (85.28 and 181.88 $\mathrm{mM}$ ), respectively, had the highest OA molar concentrations required to inhibit $S$. aureus. Acetic acid and butyric acid (68.21 and $46.49 \mathrm{mM}$ ), respectively, had the next highest OA molar concentrations necessary for $S$. aureus inhibition, and formic acid and propionic acid (22.25 and $27.65 \mathrm{mM}$ ), respectively, had the lowest OA molar concentrations required to inhibit the $S$. aureus strains tested.

Table 2. Seven MRSA strains were determined out of the total 164 strains isolated from the three swine sources, 2017 lymph node tissue, 2019 pork sausage meat, and 2002 feces.

\begin{tabular}{|c|c|c|c|c|c|c|c|c|}
\hline \multicolumn{4}{|c|}{2017 LNT $^{a}$} & \multicolumn{4}{|c|}{2019 PSM $^{\mathrm{b}}$} & \multirow{2}{*}{$\begin{array}{l}2002 \text { Feces } \\
\text { FOX }\end{array}$} \\
\hline FOX $^{c}$ & OXA $^{\mathbf{d}}$ & rRNA $^{\mathrm{e}}$ & mecA & FOX & OXA & rRNA & $\operatorname{mec} A$ & \\
\hline $21 \mathrm{~L}-\mathrm{DZ} \mathrm{f}^{\mathrm{f}}$ & $21 \mathrm{~L}-\mathrm{DZ}$ & + & + & D15- $\alpha$ & D15- $\alpha$ & + & + & None \\
\hline 38L-DZ & 38L-DZ & + & + & D16-DZ & D16-DZ & + & + & \\
\hline 147L-DZ & 147L-DZ & + & + & D16a- $\alpha$ & D16a- $\alpha$ & + & + & \\
\hline 150L-DZ & 150L-DZ & + & + & \multirow{3}{*}{\multicolumn{2}{|c|}{$\begin{array}{c}56(92.9 \%) \\
3 / 52(5.8 \%)\end{array}$}} & & & \\
\hline \multirow{2}{*}{\multicolumn{2}{|c|}{$\begin{array}{l}220(22.3 \%)^{\mathbf{g}} \\
4 / 49(8.2 \%)^{\mathbf{h}}\end{array}$}} & & & & & & & $266(23.7 \%)$ \\
\hline & & & & & & & & $0 / 63(0 \%)$ \\
\hline
\end{tabular}

${ }^{\mathrm{a}} \mathrm{LNT}=$ mandibular lymph node tissue; ${ }^{\mathrm{b}} \mathrm{PSM}=$ pork sausage meat; ${ }^{\mathrm{c}} \mathrm{FOX}=$ cefoxitin; ${ }^{\mathrm{d}} \mathrm{OXA}=\mathrm{oxacillin}$; ${ }^{\mathrm{e}} \mathrm{Staph}$ specific $\mathrm{rRNA}$. ${ }^{\mathrm{f}} \mathrm{Strain}$ designation for FOX and OXA resistant strains; ${ }^{\mathrm{g}}$ Total number of samples and (\% S. aureus positives); ${ }^{\mathrm{h}}$ Number of MRSA positive strains per number of S. aureus strains and (\% of MRSA strains).

Table 3. The MIC ${ }^{a}$ and $M I C_{M}{ }^{b}$ data measured for the 164 Staphylococcus aureus strains isolated from 2017 swine lymph node tissue, 2019 pork sausage meat and 2006 feces against the six OAs tested.

\begin{tabular}{|c|c|c|c|}
\hline Organic Acids & MICs $(\mu \mathrm{g} / \mathrm{mL})$ & $\mathrm{MIC}_{\mathrm{M}} \mathrm{s}(\mathrm{mM})$ & S. aureus strains (No.) \\
\hline \multirow[t]{3}{*}{ Acetic acid } & 4096 & 68.21 & 1 \\
\hline & 2048 & 34.1 & 111 \\
\hline & 1024 & 17.05 & 52 \\
\hline \multirow[t]{4}{*}{ Butyric acid } & 4096 & 46.49 & 5 \\
\hline & 2048 & 23.25 & 157 \\
\hline & 512 & 5.81 & 1 \\
\hline & 256 & 2.91 & 1 \\
\hline \multirow{4}{*}{ Citric acid } & 8192 & 42.64 & 13 \\
\hline & 4096 & 21.32 & 94 \\
\hline & 2048 & 10.66 & 51 \\
\hline & 128 & 0.665 & 2 \\
\hline Formic acid & 1024 & 22.25 & 164 \\
\hline \multirow[t]{3}{*}{ L-Lactic acid } & 16384 & 181.88 & 1 \\
\hline & 8192 & 90.94 & 7 \\
\hline & 2048 & 22.74 & 54 \\
\hline \multirow[t]{2}{*}{ Propionic acid } & 2048 & 27.65 & 108 \\
\hline & 1024 & 13.82 & 56 \\
\hline
\end{tabular}

${ }^{\mathrm{a}} \mathrm{MIC}=$ Minimum inhibitory concentration, ${ }^{\mathrm{b}} \mathrm{MIC}_{\mathrm{M}}=$ Molar $\mathrm{MIC}$.

Table 4 shows the central tendency of the MIC and $\mathrm{MIC}_{\mathrm{M}}$ data listed in Table 3 for 164 S. aureus strains isolated from the total number of strains from the 2006 swine feces, 2017 swine lymph node tissue, and 2019 pork sausage meat against six organic acids. The typical values observed for a probability distribution are referred to as central tendency. The largest median values were observed for L-lactic acid and acetic acid, 45.47 and $34.10 \mathrm{mM}$, respectively. The largest range values were for L-lactic, citric and acetic acid of $181.88,85.28$ and $68.21 \mathrm{mM}$, respectively, while the largest $90^{\text {th }}$ percentile values were for L-lactic and citric acid of 45.47 and $42.64 \mathrm{mM}$, respectively.

Table 4. Central tendency of the $M I C^{a}$ and $M I C_{M}{ }^{b}$ data for the 164 Staphylococcus aureus strains isolated from the combined total strains of the 2006 swine feces, 2017 swine lymph node tissue, and 2019 pork sausage meat against the six OAs tested.

\begin{tabular}{|c|c|c|c|c|}
\hline Organic Acid & Median & Mode & Range & $90^{\text {th }}$ Percentile \\
\hline \multicolumn{5}{|l|}{ Acetic Acid } \\
\hline $\mathrm{MIC}(\mu \mathrm{g} / \mathrm{mL})$ & 2048 & 2048 & $1024-4096$ & 2048 \\
\hline $\mathrm{MIC}_{\mathrm{M}}(\mathrm{mM})$ & 34.1 & 34.1 & $17.05-68.21$ & 34.1 \\
\hline \multicolumn{5}{|l|}{ Butyric Acid } \\
\hline $\mathrm{MIC}(\mu \mathrm{g} / \mathrm{mL})$ & 2048 & 2048 & $256-4096$ & 2048 \\
\hline $\mathrm{MIC}_{\mathrm{M}}(\mathrm{mM})$ & 23.25 & 23.25 & $2.91-46.49$ & 23.25 \\
\hline \multicolumn{5}{|l|}{ Citric Acid } \\
\hline $\mathrm{MIC}_{\mathrm{M}}(\mathrm{mM})$ & 21.32 & 21.32 & $0.665-85.28$ & 42.64 \\
\hline
\end{tabular}




\begin{tabular}{lllll}
\hline Organic Acid & Median & Mode & Range & 90 $^{\text {th }}$ Percentile \\
\hline Formic Acid & & & & \\
MIC $(\mu \mathrm{g} / \mathrm{mL})$ & 1024 & 1024 & 1024 & 1024 \\
MIC $(\mathrm{mM})$ & 22.25 & 22.25 & 22.25 & 22.25 \\
L-Lactic Acid & & & \\
MIC $(\mu \mathrm{g} / \mathrm{mL})$ & 4096 & 4096 & $2048-16384$ & 4096 \\
MIC $(\mathrm{mM})$ & 45.47 & 45.47 & $22.74-181.88$ & 45.47 \\
Propionic Acid & & & \\
MIC $(\mu \mathrm{g} / \mathrm{mL})$ & 2048 & 2048 & $1024-2048$ & 2048 \\
MIC $_{M}(\mathrm{mM})$ & 27.65 & 27.65 & $13.82-27.65$ & 27.65 \\
\hline
\end{tabular}

${ }^{\mathrm{a}} \mathrm{MIC}=$ Minimum inhibitory concentration. ${ }^{\mathrm{b}} \mathrm{MIC}_{\mathrm{M}}=$ Molar MIC.

\subsubsection{Results for the $52 \mathrm{~S}$. aureus Strains Isolated from the 2019 Pork Sausage Meat}

The MIC and $\mathrm{MIC}_{\mathrm{M}}$ data for $52 \mathrm{~S}$. aureus strains isolated from 2019 pork sausage meat against the six OAs are shown in Table 5. Butyric and L-lactic acid, 46.49 and $45.47 \mathrm{mM}$, respectively, had the highest OA molar concentrations for inhibition of $S$. aureus. Acetic and propionic acid, 34.10 and $27.65 \mathrm{mM}$, respectively, had the next highest OA molar concentrations for $S$. aureus inhibition, and citric and formic acid, 21.32 and $22.25 \mathrm{mM}$, respectively, had the lowest OA molar concentrations.

Table 6 shows the central tendency of the MIC and $\mathrm{MIC}_{\mathrm{M}}$ data listed in Table 5 for the $52 \mathrm{~S}$. aureus strains isolated from the 2019 pork sausage meat tested against six organic acids. The largest molar median values were observed for butyric, L-lactic, citric, and formic acid, at 23.25, 22.74, and $22.25 \mathrm{mM}$, respectively. The largest range values were observed for butyric and L-lactic acid, 46.5 and $45.47 \mathrm{mM}$, respectively, while the largest $90^{\text {th }}$ percentile value for a $S$. aureus $\mathrm{MIC}_{\mathrm{M}}$ was for L-lactic acid, $45.47 \mathrm{mM}$.

Table 7 and Table 8 show the MICs and $\mathrm{MIC}_{\mathrm{M}} \mathrm{s}$ and Table 9 and Table 10 show the central tendency of the MICs and
$\mathrm{MIC}_{\mathrm{M}} \mathrm{s}$ for the 2006 feces and 2017 swine mandibular lymph node tissue, respectively.

\subsection{The pH for the 164 S. aureus Strains at Their MICs Against the Six $\mathrm{OAs}$}

The $\mathrm{pH}$ values obtained for all $S$. aureus strains $(\mathrm{n}=164)$ were grouped for each $\mathrm{OA}$, resulting in six groups. These experimentally determined $\mathrm{pH}$ values at the MICs of the $164 \mathrm{~S}$. aureus strains were plotted against the $\mathrm{MIC}_{\mathrm{M}} \mathrm{S}$ for each of the OAs (Figure 1). In Figure 1 the number of strains at each MIC are shown next to the data points, and the $\mathrm{pH}$ values are the average of triplicate samples with the standard deviation (SD) shown at each data point. Acetic acid inhibits $100 \%$ of the $S$. aureus strains at a $\mathrm{pH}$ of 4.4 , butyric and formic acid inhibits $100 \%$ of the strains at a $\mathrm{pH}$ of 4.64 and 4.66 , respectively, while propionic acid inhibits $100 \%$ of the strains at the $\mathrm{pH}$ of 4.94 . Therefore, there is $0.54 \mathrm{pH}$ unit difference in these inhibition values. However, L-lactic and citric acid inhibit $100 \%$ of the $S$. aureus strains at the $\mathrm{pH}$ of 3.59 and 3.07, respectively. The difference in these two sets of OAs is approximately $\Delta=1.33 \mathrm{pH}$ unit.

Table 5. The $M I C^{a}$ and $M I C_{M}{ }^{b}$ data for the 52 Staphylococcus aureus strains isolated from the 2019 swine pork sausage meat against the six OAs tested.

\begin{tabular}{llll}
\hline Organic Acids & MICs $(\boldsymbol{\mu g} / \mathbf{m L})$ & $\mathbf{M I C}_{\mathbf{M}} \mathbf{s}(\mathbf{m M})$ & S. aureus strains $($ No.) \\
\hline Acetic acid & 2048 & 34.1 & 3 \\
& 1024 & 17.05 & 49 \\
Butyric acid & 4096 & 46.49 & 1 \\
& 2048 & 23.25 & 51 \\
Citric acid & 4096 & 21.32 & 8 \\
& 2048 & 10.66 & 44 \\
Formic acid & 1024 & 22.25 & 52 \\
L-Lactic acid & 4096 & 45.47 & 19 \\
& 2048 & 22.74 & 33 \\
Propionic acid & 2048 & 27.65 & 18 \\
& 1024 & 13.82 & 34 \\
\hline
\end{tabular}

${ }^{\mathrm{a}} \mathrm{MIC}=$ Minimum inhibitory concentration. ${ }^{\mathrm{b}} \mathrm{MIC} \mathrm{M}_{\mathrm{M}}=\mathrm{Molar} \mathrm{MIC}$.

Table 6. Central tendency of the $M I C^{a}$ and $M I C_{M}{ }^{b}$ data for the 52 Staphylococcus aureus strains isolated from the 2019 pork sausage meat against the six OAs tested.

\begin{tabular}{|c|c|c|c|c|}
\hline Organic Acid & Median & Mode & Range & $90^{\text {th }}$ Percentile \\
\hline \multicolumn{5}{|l|}{ Acetic Acid } \\
\hline $\mathrm{MIC}(\mu \mathrm{g} / \mathrm{mL})$ & 1024 & 1024 & 1024-2048 & 1024 \\
\hline $\mathrm{MIC}_{\mathrm{M}}(\mathrm{mM})$ & 17.05 & 17.05 & $17.05-34.1$ & 17.05 \\
\hline $\mathrm{MIC}(\mu \mathrm{g} / \mathrm{mL})$ & 2048 & 2048 & $2048-4096$ & 2048 \\
\hline $\mathrm{MIC}_{\mathrm{M}}(\mathrm{mM})$ & 23.25 & 23.25 & $23.25-46.5$ & 23.25 \\
\hline \multicolumn{5}{|l|}{ Citric Acid } \\
\hline $\mathrm{MIC}_{\mathrm{M}}(\mathrm{mM})$ & 10.66 & 10.66 & $10.66-21.32$ & 21.32 \\
\hline
\end{tabular}




\begin{tabular}{lllll}
\hline Organic Acid & Median & Mode & Range & 90 $^{\text {th }}$ Percentile \\
\hline Formic Acid & & & & \\
MIC $(\mu \mathrm{g} / \mathrm{mL})$ & 1024 & 1024 & 1024 & 1024 \\
MIC $_{\mathrm{M}}(\mathrm{mM})$ & 22.25 & 22.25 & 22.25 & 22.25 \\
L-Lactic Acid & & & \\
MIC $(\mu \mathrm{g} / \mathrm{mL})$ & 2048 & 2048 & $2048-4096$ & 4096 \\
MIC $(\mathrm{mM})$ & 22.74 & 22.74 & $22.74-45.47$ & 45.47 \\
Propionic Acid & & & & \\
MIC $(\mu \mathrm{g} / \mathrm{mL})$ & 1024 & 1024 & $1024-2048$ & 2048 \\
MIC $_{\mathrm{M}}(\mathrm{mM})$ & 13.82 & 13.82 & $13.82-27.65$ & 27.65 \\
\hline
\end{tabular}

${ }^{\mathrm{a}} \mathrm{MIC}=$ Minimum inhibitory concentration. ${ }^{\mathrm{b}} \mathrm{MIC}_{\mathrm{M}}=$ Molar MIC.

Table 7. The Staphylococcus aureus $M I C s^{a}$ and $M I C_{M} S^{b}$ for 63 strains isolated from 2006 swine feces against six organic acids.

\begin{tabular}{llll}
\hline Organic Acids & MICs $(\boldsymbol{\mu g} / \mathbf{m L})$ & MIC $_{\mathbf{M}} \mathbf{s}(\mathbf{m M})$ & S. aureus strains $(\mathbf{N o}$ ) \\
\hline Acetic acid & 4096 & 68.21 & 1 \\
& 2048 & 34.10 & 59 \\
& 1024 & 17.05 & 3 \\
Butyric acid & 2048 & 23.25 & 61 \\
& 512 & 5.81 & 1 \\
Citric acid & 256 & 2.91 & 1 \\
& 16384 & 85.28 & 3 \\
& 8192 & 42.64 & 4 \\
& 4096 & 21.32 & 51 \\
Formic acid & 2048 & 10.66 & 3 \\
L-Lactic acid & 128 & 0.665 & 2 \\
& 1024 & 22.25 & 63 \\
& 16384 & 181.88 & 1 \\
Propionic acid & 8192 & 90.94 & 3 \\
& 4096 & 45.47 & 47 \\
& 2048 & 22.74 & 12 \\
\hline
\end{tabular}

${ }^{\mathrm{a}} \mathrm{MICs}=$ Minimum inhibitory concentrations. ${ }^{\mathrm{b}} \mathrm{MIC}_{\mathrm{M}} \mathrm{S}=$ Molar MICs.

Table 8. The Staphylococcus aureus $M I C S^{a}$ and $M I C_{M} S^{b}$ for 49 strains isolated from 2017 swine mandibular lymph node tissue against six organic acids.

\begin{tabular}{llll}
\hline Organic Acids & MICs $(\boldsymbol{\mu g} / \mathbf{m L})$ & MIC $_{\mathbf{M}} \mathbf{s}(\mathbf{m M})$ & S. aureus strains $($ No.) \\
\hline Acetic acid & 2048 & 34.10 & 49 \\
Butyric acid & 4096 & 46.50 & 4 \\
& 2048 & 23.25 & 45 \\
Citric acid & 16384 & 85.28 & 1 \\
& 8192 & 42.64 & 9 \\
& 4096 & 21.32 & 35 \\
Formic acid & 2048 & 10.66 & 4 \\
L-Lactic acid & 1024 & 22.25 & 49 \\
& 8192 & 90.94 & 4 \\
& 4096 & 45.47 & 36 \\
Propionic acid & 2048 & 22.74 & 9 \\
& 2048 & 27.65 & 46 \\
\hline
\end{tabular}

${ }^{\mathrm{a}} \mathrm{MICs}=$ Minimum inhibitory concentrations. ${ }^{\mathrm{b}} \mathrm{MIC}_{\mathrm{M}} \mathrm{s}=$ Molar MICs.

Table 9. Central tendency of the Staphylococcus aureus $M I C s^{a}$ and $M I C_{M} S^{a}$ for 63 strains isolated from the 2006 swine feces against six organic acids.

\begin{tabular}{lllll}
\hline Organic Acid & Median & Mode & Range & 90 $^{\text {th }}$ Percentile \\
\hline Acetic Acid & & & & 2048 \\
MIC $(\mu \mathrm{g} / \mathrm{mL})$ & 2048 & 2048 & $1024-4096$ & 34.1 \\
MIC $_{\mathrm{M}}(\mathrm{mM})$ & 34.1 & 34.1 & $17.05-68.21$ & 2048 \\
Butyric Acid & & & $256-2048$ & 23.25 \\
MIC $(\mu \mathrm{g} / \mathrm{mL})$ & 2048 & 2048 & $2.91-23.25$ & 8192 \\
MIC $(\mathrm{mM})$ & 23.25 & 23.25 & & 42.64 \\
Citric Acid & & 4096 & $128-16384$ & $0.665-85.28$ \\
MIC $(\mu \mathrm{g} / \mathrm{mL})$ & 4096 & 21.32 & & \\
MIC $(\mathrm{mM})$ & 21.32 & & & \\
Formic Acid & & & & \\
\hline
\end{tabular}




\begin{tabular}{lllll}
\hline Organic Acid & Median & Mode & Range & 90 $^{\text {th }}$ Percentile \\
\hline MIC $(\mu \mathrm{g} / \mathrm{mL})$ & 1024 & 1024 & 1024 & 1024 \\
MIC $(\mathrm{mM})$ & 22.25 & 22.25 & 22.25 & 22.25 \\
L-Lactic Acid & & & $2048-16384$ & 4096 \\
MIC $(\mu \mathrm{g} / \mathrm{mL})$ & 4096 & 4096 & $22.74-181.88$ & 45.47 \\
MIC $(\mathrm{mM})$ & 45.47 & 45.47 & & 2048 \\
Propionic Acid & & & $1024-2048$ & 27.65 \\
MIC $(\mu \mathrm{g} / \mathrm{mL})$ & 2048 & 2048 & $13.82-27.65$ & \\
MIC $_{\mathrm{M}}(\mathrm{mM})$ & 27.65 & 27.65 & & \\
\hline
\end{tabular}

${ }^{\mathrm{a}} \mathrm{MICs}=$ Minimum inhibitory concentrations. ${ }^{\mathrm{b}} \mathrm{MIC} \mathrm{C}_{\mathrm{M}} \mathrm{s}=$ Molar MICs.

Table 10. Central tendency of the Staphylococcus aureus $M I C s^{a}$ and $M I C_{M} S^{b}$ for 49 strains isolated from the 2017 swine mandibular lymph node tissue against six organic acids.

\begin{tabular}{|c|c|c|c|c|}
\hline Organic Acid & Median & Mode & Range & $90^{\text {th }}$ Percentile \\
\hline \multicolumn{5}{|l|}{ Acetic Acid } \\
\hline $\mathrm{MIC}(\mu \mathrm{g} / \mathrm{mL})$ & 2048 & 2048 & 4096 & 2048 \\
\hline $\mathrm{MIC}_{\mathrm{M}}(\mathrm{mM})$ & 34.1 & 34.1 & 34.1 & 34.1 \\
\hline \multicolumn{5}{|l|}{ Butyric Acid } \\
\hline $\mathrm{MIC}(\mu \mathrm{g} / \mathrm{mL})$ & 2048 & 2048 & 2048-4096 & 2048 \\
\hline $\mathrm{MIC}_{\mathrm{M}}(\mathrm{mM})$ & 23.25 & 23.25 & $23.25-46.5$ & 23.25 \\
\hline \multicolumn{5}{|l|}{ Citric Acid } \\
\hline $\mathrm{MIC}(\mu \mathrm{g} / \mathrm{mL})$ & 4096 & 4096 & 2048-16384 & 8192 \\
\hline $\mathrm{MIC}_{\mathrm{M}}(\mathrm{mM})$ & 21.32 & 21.32 & $10.66-85.28$ & 42.64 \\
\hline \multicolumn{5}{|l|}{ Formic Acid } \\
\hline $\mathrm{MIC}(\mu \mathrm{g} / \mathrm{mL})$ & 1024 & 1024 & 1024 & 1024 \\
\hline $\mathrm{MIC}_{\mathrm{M}}(\mathrm{mM})$ & 22.25 & 22.25 & 22.25 & 22.25 \\
\hline \multicolumn{5}{|l|}{ L-Lactic Acid } \\
\hline $\mathrm{MIC}(\mu \mathrm{g} / \mathrm{mL})$ & 4096 & 4096 & $2048-8192$ & 4096 \\
\hline $\mathrm{MIC}_{\mathrm{M}}(\mathrm{mM})$ & 45.47 & 45.47 & $22.74-90.94$ & 45.47 \\
\hline \multicolumn{5}{|l|}{ Propionic Acid } \\
\hline $\mathrm{MIC}(\mu \mathrm{g} / \mathrm{mL})$ & 2048 & 2048 & 1024-2048 & 2048 \\
\hline $\mathrm{MIC}_{\mathrm{M}}(\mathrm{mM})$ & 27.65 & 27.65 & $13.82-27.65$ & 27.65 \\
\hline
\end{tabular}

${ }^{\mathrm{a}} \mathrm{MICs}=$ Minimum inhibitory concentrations. ${ }^{\mathrm{b}} \mathrm{MIC}_{\mathrm{M}} \mathrm{s}=$ Molar MICs.

The $\mathrm{pH}$ vs $\mathrm{MIC}_{\mathrm{M}} \mathrm{s}$ of the $S$. aureus strains isolated from 2006 swine feces are shown in Figure 2, from 2017 mandibular lymph node tissue are shown in Figure 3, and from 2019 pork sausage meat are shown in Figure 4.
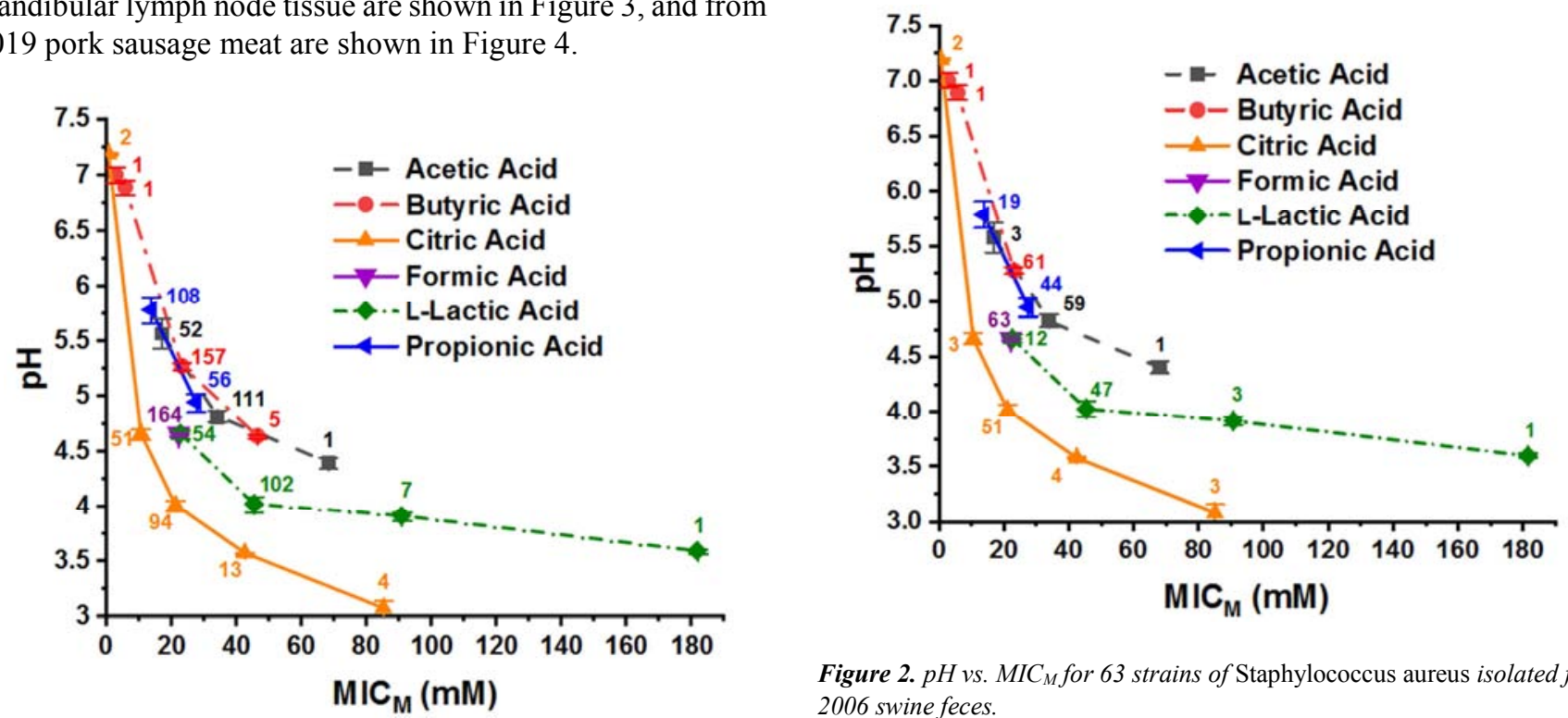

Figure 1. pHvs. MIC for $_{164}$ total strains of Staphylococcus aureus isolated from swine.

Figure 2. $p H$ vs. $M I C_{M}$ for 63 strains of Staphylococcus aureus isolated from 2006 swine feces. 


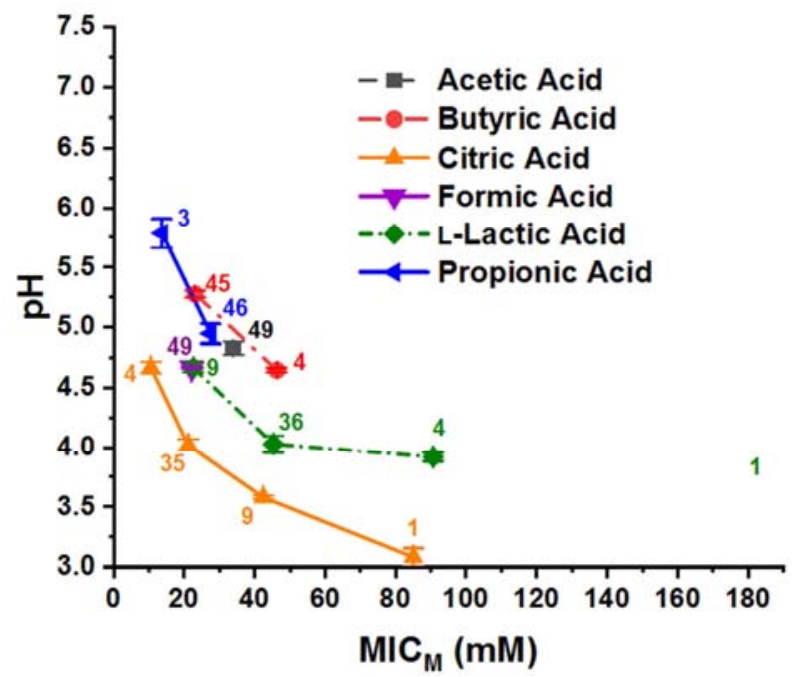

Figure 3. $p H$ vs. $M I C_{M}$ for 49 strains of Staphylococcus aureus isolated from 2017 swine mandibular lymph node tissue.

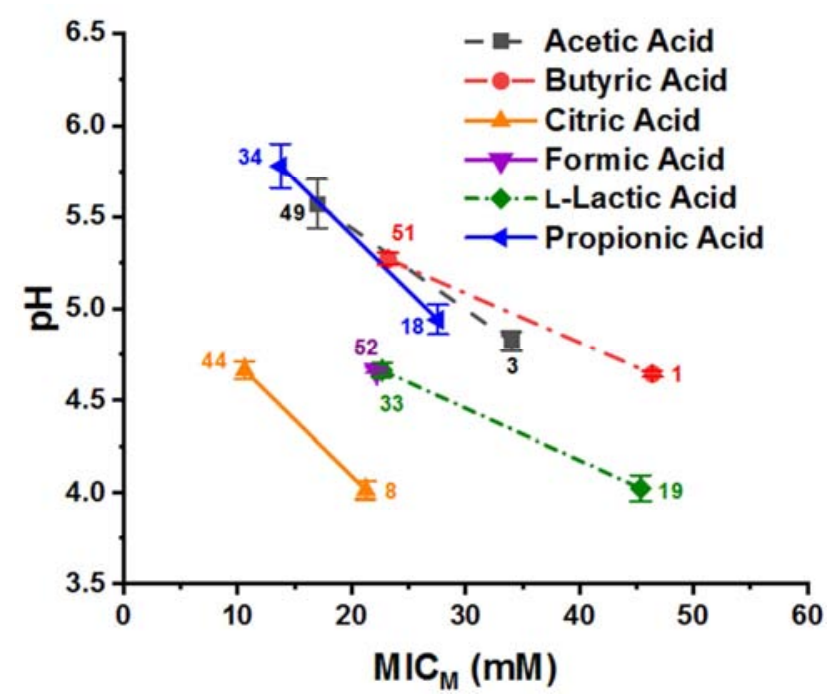

Figure 4. $p H$ vs. $M I C_{M}$ for 52 strains of Staphylococcus aureus isolated from 2019 pork sausage batter.

\subsection{The Calculated Molar Undissociated $\mathrm{OA}$ \\ Concentrations at the $\mathrm{S}$. aureus $\mathrm{MIC}_{M} \mathrm{~S}$}

The molar concentrations of undissociated OAs were calculated at the $\mathrm{MIC}_{\mathrm{M}} \mathrm{S}$ for the six OAs, citric, L-lactic, butyric, acetic, propionic, and formic acid using the Henderson-Hasselbalch equation and the plot is depicted in Figure 5. The number of $S$. aureus strains at each MIC is shown next to the data points. The levels of the undissociated OAs calculated at the MICs for $100 \%$ of the S. aureus strains against citric, L-lactic, butyric, and acetic acid are 46.07, $118.33,27.74$, and $47.16 \mathrm{mM}$, respectively. But, the undissociated propionic and formic acid levels required for inhibition of $100 \%$ of the same strains were 12.71 and 2.44 $\mathrm{mM}$, respectively. The difference between the undissociated acetic and undissociated formic acid levels needed for inhibition of $100 \%$ of the strains was $\Delta=44.72 \mathrm{mM}$, shown by the light grey box in Figure 5 .

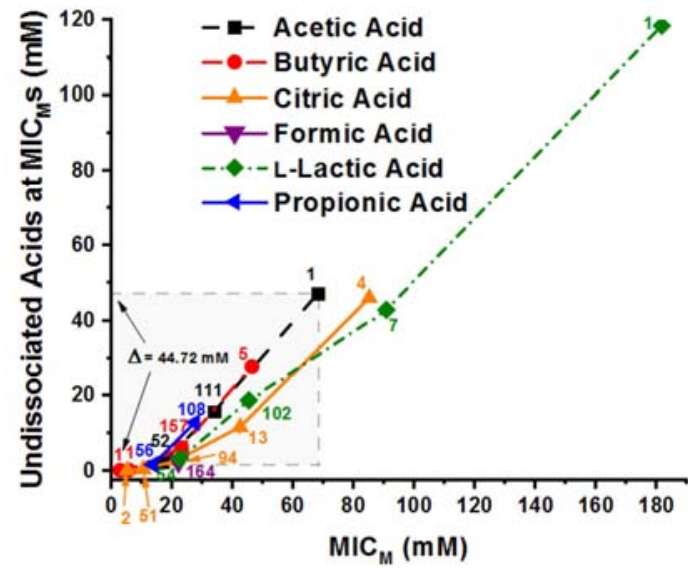

Figure 5. The concentration of undissociated OAs at the MIC $C_{M S}$ for 164 total isolates of Staphylococcus aureus from swine. 100\% of all isolates were inhibited by acetic, butyric, formic, and propionic acids over a concentration range of $\Delta=44.72 \mathrm{mM}$; acetic acid at $47.16 \mathrm{mM}$ - formic acid at $2.44 \mathrm{mM}$.

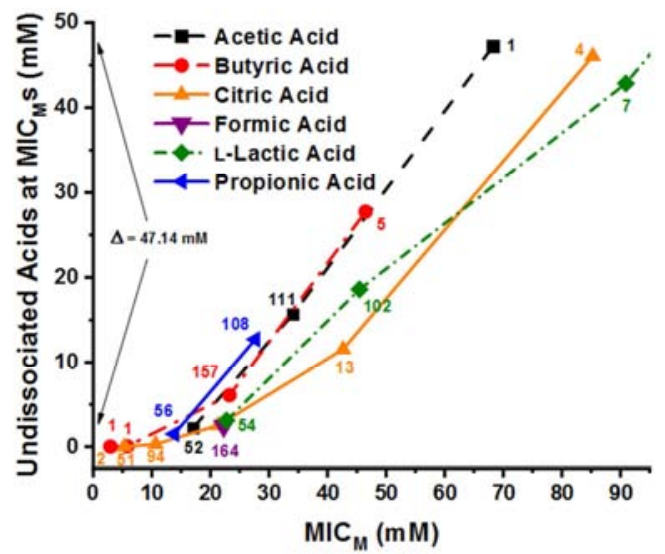

Figure 6. The concentration of undissociated OAs at the MIC $C_{M S}$ for 164 total isolates of Staphylococcus aureus from swine. $100 \%$ of all isolates were inhibited by acidic, butyric, formic, and propionic acid over a concentration range of $\Delta=44.72 \mathrm{mM}$; acetic acid at $47.16 \mathrm{mM}$ - formic acid at $2.438 \mathrm{mM}$. Expanded version of Figure 5 for visual purposes.

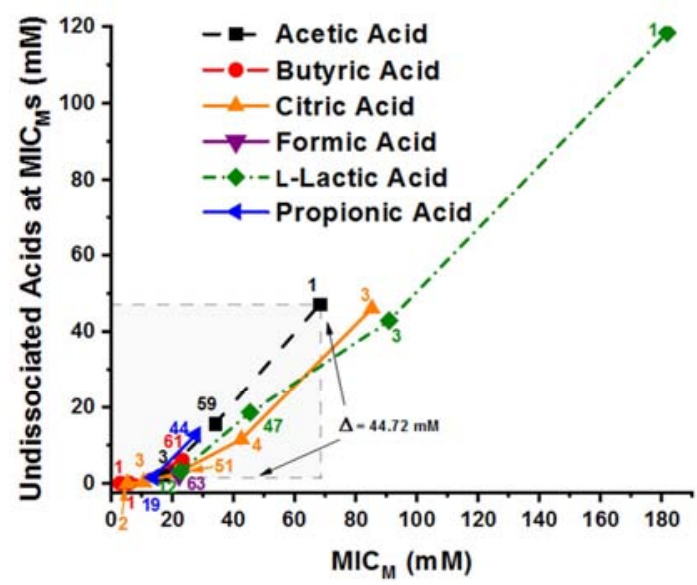

Figure 7. The concentration of undissociated OAs at the $M I C_{M}$ S for 63 strains of Staphylococcus aureus isolated from 2006 swine feces.

An expanded version of Figure 5 can be found in Figure 6 . The concentrations of the undissociated $\mathrm{OAs}$ vs $\mathrm{MIC}_{\mathrm{M}} \mathrm{s}$ of the 
S. aureus strains isolated from 2006 feces are shown in Figure 7, from 2017 mandibular lymph node tissue are shown in Figure 8, and from 2019 pork sausage are shown in Figure 9.

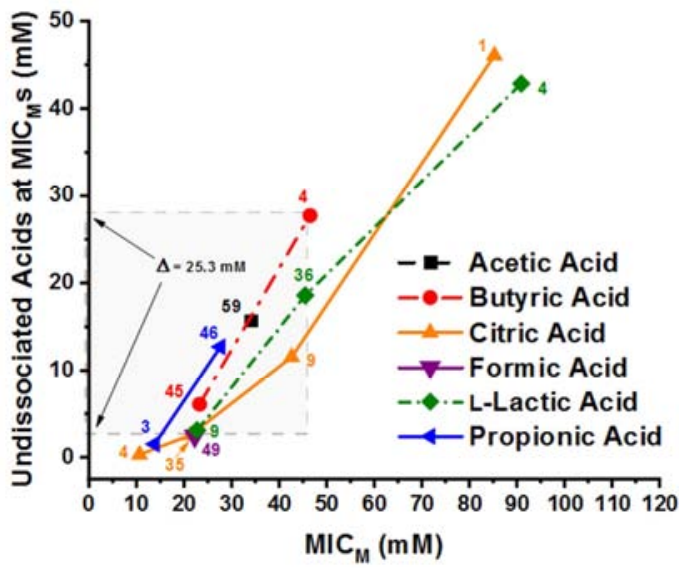

Figure 8. The concentration of undissociated OAs at the $M I C_{M S}$ for 49 strains of Staphylococcus aureus isolated from 2017 swine mandibular lymph node tissue.

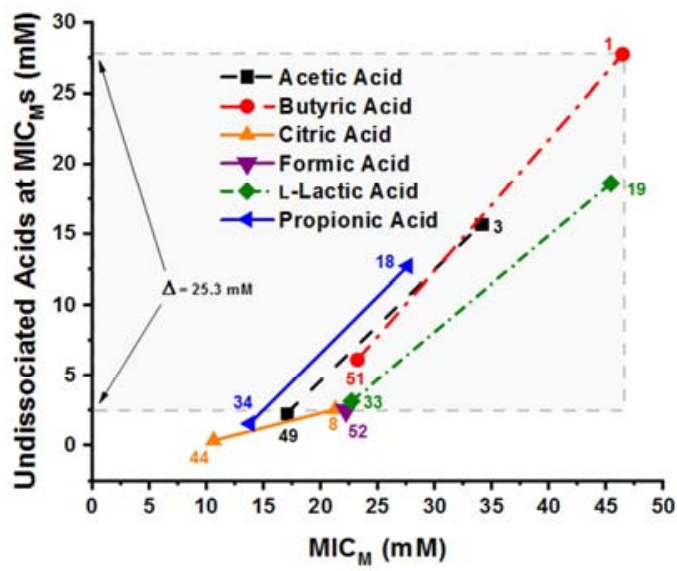

Figure 9. The concentration of undissociated $O A$ s at the $M I C_{M}$ for 52 strains of Staphylococcus aureus isolated from 2019 pork sausage meat.

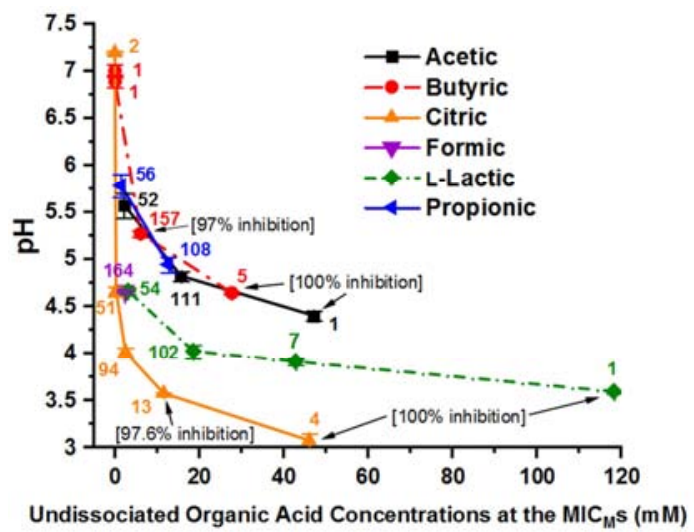

Figure 10. $p H$ vs. the undissociated $O A$ concentrations at the $M I C_{M}$ for 164 total Staphylococcus aureus strains from swine. Butyric acid (pH 5.27) (97\%) - citric acid ( $p H 3.57)(97.6 \%)=\Delta 1.7$ pH units. Butyric acid (pH 4.64) (100\%) - citric acid $(p H 3.07)(100 \%)=\Delta 1.57 \mathrm{pH}$ units.

The $\mathrm{pH}$ versus the molar concentrations of undissociated OAs at the $\mathrm{MIC}_{\mathrm{M}} \mathrm{S}$ of the $164 \mathrm{~S}$. aureus strains is depicted in
Figure 10. The number of $S$. aureus strains at each MIC is shown next to the data points. The difference in $\mathrm{pH}$ between inhibition of $100 \%$ of the $S$. aureus strains by propionic and acetic acid is $\Delta=0.54 \mathrm{pH}$ unit, and the difference in undissociated OA between these two data points for propionic and acetic acid is $\Delta=34.45 \mathrm{mM}$. The difference between inhibition of $100 \%$ of the $S$. aureus strains by propionic and L-lactic acid is $\Delta=1.35 \mathrm{pH}$ units, and the difference between inhibition of $100 \%$ of the $S$. aureus strains by propionic and citric acid is $\Delta=1.87 \mathrm{pH}$ units.

\subsection{The Calculated Molar Dissociated OA Concentrations at the $\mathrm{S}$. aureus $\mathrm{MIC}_{M} \mathrm{~S}$}

The molar concentrations of the dissociated OAs, citric, L-lactic, butyric, acetic, propionic, and formic acid were calculated with the Henderson-Hasselbalch equation using the determined $\mathrm{pH}$ data and known concentrations of OAs at the MICs of the 164 S. aureus strains and plotted as depicted in Figure 11. The number of $S$. aureus strains at each MIC is shown next to the data points. The maximum molar concentration of dissociated OAs needed to inhibit $100 \%$ of the $S$. aureus strains against butyric, acetic, propionic, and formic acid are shown within the grey-shaded rectangle. The two acids that encompass the grey-shaded rectangle are acetic and propionic acid, with a difference in concentration of $\Delta=6.11 \mathrm{mM}$ dissociated OA. $100 \%$ of the $S$. aureus strains inhibited by dissociated propionic acid is achieved at 14.94 $\mathrm{mM}$ and the molar concentration of dissociated acetic acid required to inhibit $100 \%$ of the bacteria was at $21.05 \mathrm{mM}$. The citric and L-lactic acid concentrations are affected by $S$. aureus utilization of these acids.

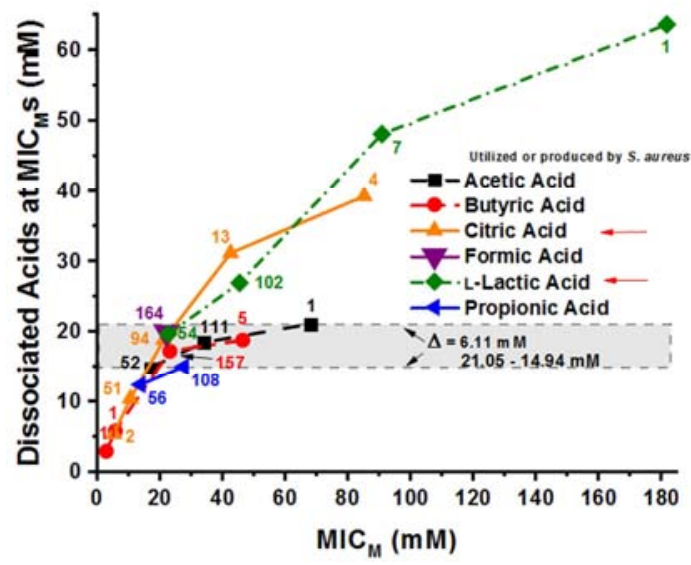

Figure 11. The concentration of dissociated organic acids at the $M I C_{M S}$ for 164 total isolates of Staphylococcus aureus from swine. 100\% of all isolates were inhibited by acetic, butyric, formic, and propionic acids with a difference in concentration of $\Delta=6.11 \mathrm{mM} ; 21.05 \mathrm{mM}$ acetic $-14.94 \mathrm{mM}$ propionic acid.

An expanded version of Figure 11 can be seen in Figure 12. The concentrations of the dissociated OAs vs $\mathrm{MIC}_{\mathrm{M}} \mathrm{S}$ of the $S$. aureus strains isolated from 2006 swine feces are shown in Figure 13, from 2017 swine mandibular lymph node tissue are shown in Figure 14, and from 2019 pork sausage meat are shown in Figure 15. 


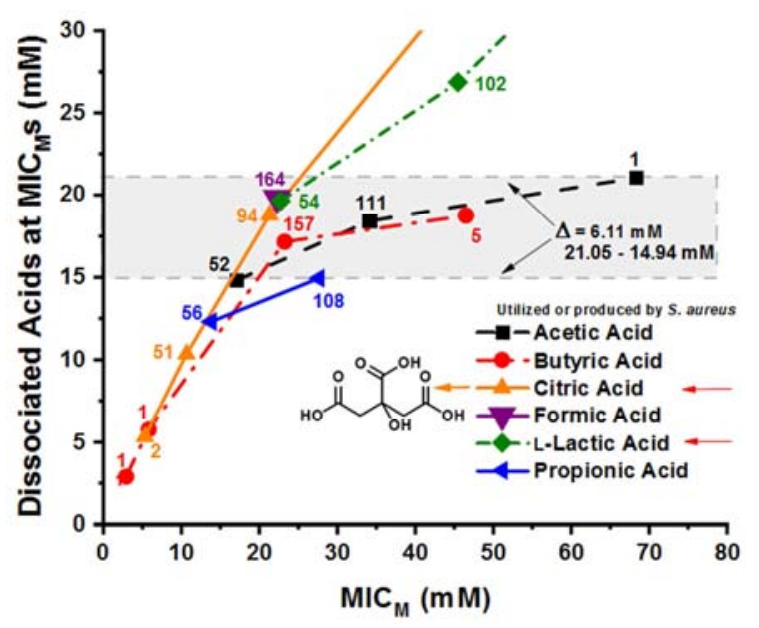

Figure 12. The concentration of dissociated organic acids at the $M I C_{M S}$ for 164 total isolates of Staphylococcus aureus from swine. 100\% of all isolates were inhibited by acetic, butyric, formic, and propionic acid with a difference in concentration of $\Delta=6.11 \mathrm{mM} ; 21.05 \mathrm{mM}$ acetic acid $-14.94 \mathrm{mM}$ propionic acid. This is an expanded version of Figure 11 for visual reasons.

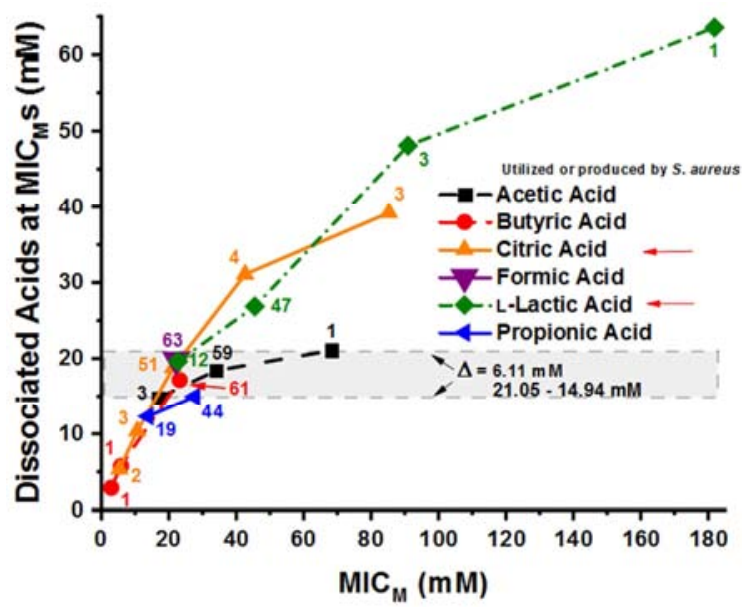

Figure 13. The concentration of dissociated organic acids at the MIC $C_{M S}$ for 63 strains of Staphylococcus aureus isolated from 2006 swine feces.

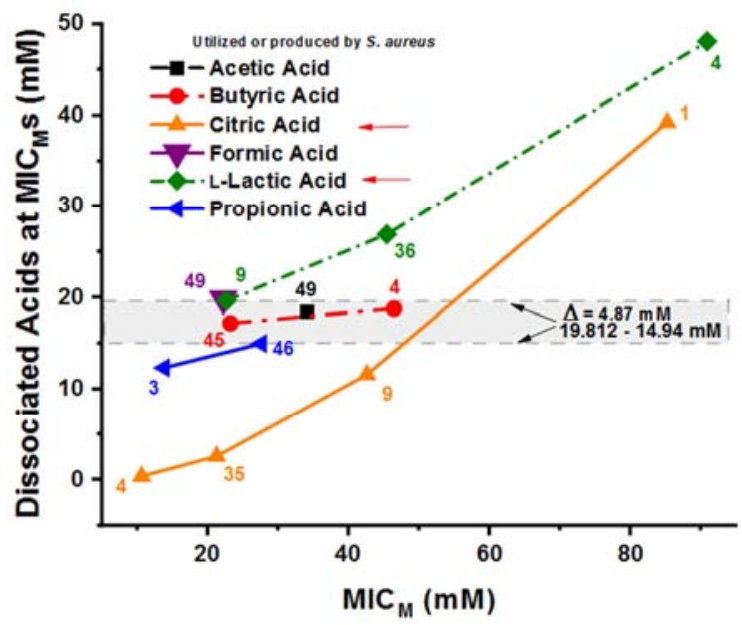

Figure 14. The concentration of dissociated organic acids at the MIC $C_{M S}$ for 49 strains of Staphylococcus aureus isolated from 2017 swine mandibular lymph node tissue.

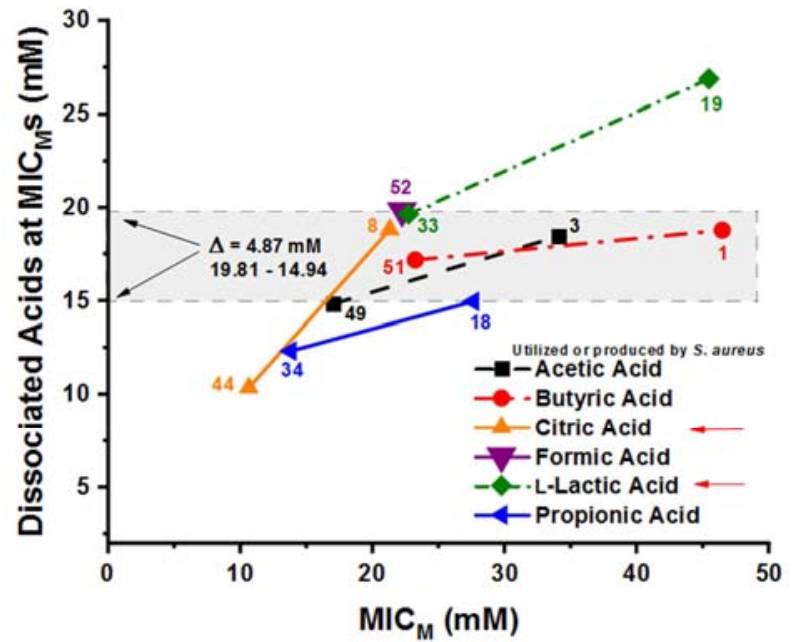

Figure 15. The concentration of dissociated organic acids at the $M I C_{M S}$ for 52 strains of Staphylococcus aureus isolated from 2019 pork sausage meat.

The molar concentrations of the dissociated OAs, citric, L-lactic, butyric, acetic, propionic, and formic acid versus the $\mathrm{pH}$ determined at the MICs of the $S$. aureus strains are plotted in Figure 16. The number of $S$. aureus strains at each MIC is shown next to the data points. The $S$. aureus strains are all inhibited by the dissociated OAs butyric, formic, propionic, and acetic acid at or below the concentration of dissociated acetic acid $(21.05 \mathrm{mM})$ indicated by the narrow light grey vertical box. These four OAs inhibit $100 \%$ of the $S$. aureus strains over the range of 14.94-21.05 mM OA. Whereas, $97.6 \%$ of the strains are inhibited by citric acid (narrow light orange vertical box) at a dissociated acid concentration of $31.09 \mathrm{mM}$, and $99.4 \%$ of the strains are inhibited by L-lactic acid (narrow light green vertical box) at a dissociated acid concentration of $48.08 \mathrm{mM}$.

\section{Discussion}

Staphylococcus aureus is commonly known as both a commensal and a pathogen in animals and humans [10]. Pigs are commonly known to be colonized by $S$. aureus bacteria [9], which can result in a reservoir of MRSA at the pig farm [10, 15]. Therefore, workers that have occupational exposure to swine production facilities are at risk of being a carrier of MRSA [20]. When pigs are transported to the abattoir for processing, they bring colonized S. aureus and MRSA with them [19]. Various methods have been used to remove $S$. aureus and other bacterial contamination from swine carcasses, like dehairing $[10,75]$, singeing [10], scalding water [76, 77], OA carcass washes $[42,46]$, and cut meat OA surface washes [41]. But even with all the applied methods available to decontaminate swine carcasses and meat cuts to remove contaminating bacteria, final pork products still end up with $S$. aureus and MRSA contamination [34, 35, 78]. 


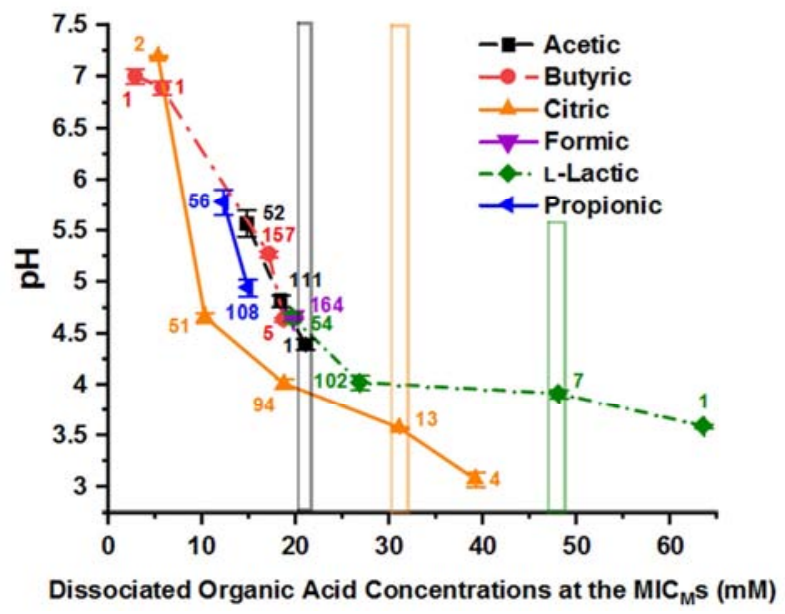

Figure 16. $p H$ vs. dissociated organic acid concentrations at the $M I C_{M S}$ for 164 total Staphylococcus aureus strains isolated from swine. The grey box shows the concentration of dissociated acetic acid that inhibits $100 \%$ of the isolates. The light orange box shows the concentration of dissociated citric acid that inhibits $97.6 \%$ of the isolates. The light green box shows the concentration of lactic acid the inhibits $99.4 \%$ of the isolates.

Many foodborne pathogens can adapt to varying $\mathrm{pH}$ environments and to numerous decontamination strategies based on $\mathrm{pH}$ [79]. We have isolated $164 \mathrm{~S}$. aureus strains from swine mandibular lymph node tissue, commercial pork sausage meat and swine feces, and the susceptibility of these strains was evaluated against six OAs, citric, L-lactic, butyric, acetic, propionic, and formic acid to determine the inhibition mode of action of the OAs. Similar MICs were observed for the strains isolated from pork sausage meat as for those isolated from other swine sources, except for the MICs against citric and L-lactic acid. The MICs for these two OAs are higher for the strains isolated from mandibular lymph node tissue and swine feces than for the strains from pork sausage meat.

\subsection{S. aureus Was Found Intracellularly in Swine Lymph Node Tissue}

Upon evaluation of the 164 S. aureus strains with cefoxitin and oxacillin antibiotics and PCR studies, seven strains were determined to be MRSA. The feces strains contained $S$. aureus strains, but none were MRSA. S. aureus strains were found in both the mandibular lymph node tissue and pork sausage meat, and both sources contained MRSA strains at 4/49 (8.2\%) and $3 / 52(5.8 \%)$, respectively. The pork sausage meat contamination may well be from cross-contaminated meat cuts. However, the lymph node tissue was specifically removed from the swine carcasses by hand and later immersed in boiling water to surface sterilize the tissue. Therefore, one would expect the hand removed tissue to have very low numbers of bacteria including MRSA, but that was not the case. These results indicate that $S$. aureus bacteria had invaded the tissue and were within the tissue of the swine lymph nodes (intracellular). Mann and coworkers have shown a large array of bacteria in swine lymph nodes, including Salmonella and Staphylococcus among others [80, 81]. These lymph nodes may remain on the carcasses following slaughter and end up in ground meat and sausage products [82]. Studies conducted to determine the percentage of MRSA in final pork products consistently demonstrate a prevalence of 2.2-6.6\% MRSA [34, $35,79]$. Based on the findings of our study showing $8.2 \%$ intracellular MRSA contamination in swine lymph node tissue, it is likely that the prevalence of MRSA determined in final pork products is not primarily from surface contamination but rather from bacterial intracellular invasion.

\section{2. pH Differences at the S. aureus $M I C_{M} S$ Tested Against Solutions Containing Different $\mathrm{OAs}$}

A difference of $0.55 \mathrm{pH}$ unit was observed when inhibiting $100 \%$ of the strains by propionic, butyric, formic, and acetic acid. A difference of $1.87 \mathrm{pH}$ unit was observed when inhibiting $100 \%$ of the strains by all OAs, propionic - citric acid, $4.94-3.07 \mathrm{pH}$, respectively. If only $\mathrm{pH}$ is assumed to be the important attribute of OAs for inhibiting bacteria, then acid-resistant pathogens [79, 83-85] may be a real threat in OA acidified foods [55]. However, acidified food products without heat treatments have been safely made for many years [86]. Also, if $\mathrm{pH}$ were the primary cause of $S$ aureus inhibition, then it would be expected that MICs for the same bacteria against different OAs would be observed at very similar $\mathrm{pH}$ values, but that is not what we observed. Our laboratory has previously published the differences in $\mathrm{pH}$ between the inhibition of Gram-positive and Gram-negative bacterial species by OAs. The change in $\mathrm{pH}$ for $100 \%$ of vancomycin-resistant Enterococcus faecium (VRE) strains against all six OAs was $1.1 \mathrm{pH}$ units [68]. Ninety-eight percent of 175 Pseudomonas aeruginosa strains were inhibited by different OAs by a difference of $0.98 \mathrm{pH}$ unit [64]. Ninety-eight percent of 344 Escherichia coli O157:H7 strains were inhibited by three different OAs by a difference of 0.56 $\mathrm{pH}$ unit [63]. All 138 non-O157 Shiga toxin-producing E. coli strains were inhibited by four OAs by a difference of $0.99 \mathrm{pH}$ unit [65]. Ninety-five percent of 145 Salmonella strains were inhibited by four different OAs by a difference of $1.1 \mathrm{pH}$ unit [66]. One hundred percent of 111 Campylobacter coli strains were inhibited by all six OAs by a difference of $1.76 \mathrm{pH}$ units [62]. Ninety-seven to ninety-nine percent of 96 C. jejuni strains were inhibited by all six OAs with a difference of an average of $1.34 \mathrm{pH}$ units [67]. In other studies, it was shown that two different acids, acetic acid and HCL, inhibited E. coli O157:H7 at different $\mathrm{pH}$ values, 5.5 and $4.5 \mathrm{pH}$, respectively, for a difference of $\Delta=1 \mathrm{pH}$ unit apart [87]. The inhibition of $S$. aureus in this study as well as the previous studies demonstrate that bacterial inhibition is not dependent on $\mathrm{pH}$, as other researchers have hypothesized [88]. Therefore, bacterial inhibition by OAs must then be attributable to some other characteristic of OAs [67, 89].

\subsection{The Relationship of Undissociated $O A$ Concentrations to the $\mathrm{MIC}_{M}$ Concentrations and $\mathrm{pH}$}

S. aureus strains (163 of 164) were inhibited by the six undissociated OAs, citric, butyric, acetic, formic, L-lactic and propionic acid between the concentrations of undissociated 
acetic and undissociated formic acid at 47.16 and $2.44 \mathrm{mM}$, respectively. This is a difference in undissociated OA levels of $\Delta=44.72 \mathrm{mM}$ required for inhibition of the same strains by all OAs. The inhibition of most of the strains by some OAs, butyric, citric, and formic acid occurred at very dilute OA concentrations, 6.09, 2.53, and $2.44 \mathrm{mM}$, respectively, if indeed the undissociated OAs were causing inhibition in $S$. aureus. There appears to be no correlation between the undissociated OA levels with respect to the $\mathrm{MIC}_{\mathrm{M}} \mathrm{S}$ of the 164 $S$. aureus strains. This result agrees with our earlier published studies of a Gram-positive and Gram-negative bacteria. Inhibition of 50 Gram-positive VREs required a difference of $\Delta=35.21 \mathrm{mM}$ undissociated OAs, and all strains would have been inhibited by undissociated citric and formic acid at a concentration of 1.9 and $2.49 \mathrm{mM}$, respectively [68]. One-hundred percent of $175 P$. aeruginosa strains were inhibited by undissociated citric and acetic acid concentrations at 2.53 and $21.65 \mathrm{mM}$, respectively, for a $\Delta=19.12 \mathrm{mM} \mathrm{OAs}$ [64]. Undissociated citric and acetic acid at 2.86 and $50.63 \mathrm{mM}$, respectively, inhibited $98.3 \%$ of 344 E. coli $\mathrm{O} 157: \mathrm{H} 7$ strains for a difference of $\Delta=47.77 \mathrm{mM}$ OAs [63]. One-hundred percent of 138 non-O157 STEC strains were inhibited by undissociated citric and acetic acid at 2.2 and $49.11 \mathrm{mM}$, respectively, for a difference of $\Delta=46.91 \mathrm{mM}$ OAs [65]. One-hundred percent of 145 Salmonella strains were inhibited by undissociated citric and acetic acid at 2.29 and $19.0 \mathrm{mM}$, respectively, for a difference of $\Delta=16.71 \mathrm{mM}$ OAs [66]. Undissociated citric and acetic acid at 0.024 and $39.93 \mathrm{mM}$, respectively, would inhibit $100 \%$ of $111 C$. coli strains for a difference of $\Delta=39.91 \mathrm{mM}$ OAs [62], and $100 \%$ of all $96 C$. jejuni strains would be inhibited by the six undissociated OAs, citric, butyric, acetic, formic, L-lactic and propionic acid with citric and L-lactic acid concentrations at 0.932 and $51.71 \mathrm{mM}$, respectfully, for a difference of $\Delta=50.78 \mathrm{mM}$ OAs [67]. The difference in the undissociated OAs required to inhibit the $S$. aureus strains tested in this study is similar to the concentrations of undissociated OAs we have seen in other studies of pathogens; having variable and high levels of undissociated OAs.

We compared the undissociated OA concentrations to the $\mathrm{pH}$ at the $\mathrm{MIC}_{\mathrm{M}} \mathrm{S}$ to obtain a further understanding of the undissociated $\mathrm{OA}$ results. When viewing the $\mathrm{pH}$ at the $S$. aureus $\mathrm{MIC}_{\mathrm{M}} \mathrm{S}$ for the 164 strains, $90 \%$ of the strains are suggested to be inhibited by an undissociated citric acid concentration at extremely low levels. All of the strains would be inhibited by undissociated acid at a $\mathrm{pH}$ nearly midway between the $\mathrm{pH}$ values from other OAs that inhibit the same strains, and the concentration of undissociated formic acid is also extremely low; whereas, other OAs like acetic and butyric required higher levels of undissociated acid, and citric and L-lactic acid could have much higher undissociated acid levels. From this perspective there is no consistent values of undissociated acids or $\mathrm{pH}$ levels that correspond with the inhibition of $S$ aureus strains.

\subsection{The Relationship of Dissociated OA Concentrations to the $M I C_{M}$ Concentrations and $\mathrm{pH}$}

One-hundred percent of the 164 S. aureus strains were inhibited by the four dissociated OAs, acetic, butyric, formic, and propionic acid within a narrow concentration range of the dissociated OAs, $21.05 \mathrm{mM}$ acetic acid - $14.94 \mathrm{mM}$ propionic acid, for a difference of $\Delta=6.11 \mathrm{mM}$ dissociated OAs. The other two OAs, citric and L-lactic acids are utilized by $S$. aureus. The results of this study are quite similar to those obtained for another Gram-positive pathogen, VRE [68]. In that study all 50 VRE strains were inhibited by the same six OAs used in this study with a narrow band of dissociated OAs, $\Delta=3.1 \mathrm{mM}$. Similarly, other Gram-negative pathogenic bacteria behaved in a like manner when challenged with OAs. Ninety-eight percent of $175 P$. aeruginosa strains were inhibited by a narrow band of two dissociated OAs bracketed by dissociated citric acid $(10.24 \mathrm{mM})$ and dissociated acetic acid $(9.98 \mathrm{mM})$ for a difference of $\Delta=0.26 \mathrm{mM}$ [64]. $98.3 \%$ of 344 E. coli $\mathrm{O} 157: \mathrm{H} 7$ strains were inhibited by a narrow band of dissociated OAs bracketed by dissociated propionic (13.82 $\mathrm{mM})$ and L-lactic acid (19.12 $\mathrm{mM})$ for a difference of $\Delta=5.54$ $\mathrm{mM}$ dissociated OAs [63]. One-hundred percent of 138 non-O157 STEC strains were inhibited by a narrow band of dissociated OAs bracketed by dissociated L-lactic $(12.93 \mathrm{mM})$ and dissociated citric acid $(19.12 \mathrm{mM})$ having a concentration difference of $\Delta=6.19 \mathrm{mM}$ dissociated OAs [65]. One-hundred percent of 145 Salmonella strains were inhibited by a narrow band of dissociated OAs bracketed by dissociated propionic $(13.67 \mathrm{mM})$ and dissociated citric acid $(19.03 \mathrm{mM})$ having a concentration difference of $\Delta=5.36 \mathrm{mM}$ dissociated OAs [66]. One-hundred percent of $111 \mathrm{C}$. coli strains were inhibited by dissociated butyric $(22.56 \mathrm{mM})$ and dissociated L-lactic acid (21.17 mM) having a concentration difference of $\Delta=1.39 \mathrm{mM}$ dissociated OAs [62]. Ninety-seven to $100 \%$ of 96 C. jejuni strains were inhibited by a narrow band of dissociated OAs bracketed by dissociated butyric $(22.72 \mathrm{mM})$ and dissociated acetic acid (24.86 $\mathrm{mM}$ ) having a concentration difference of $\Delta=4.47 \mathrm{mM}$ dissociated OAs [67]. In all these cases only a well-defined narrow range of dissociated OA concentrations were required to inhibited $100 \%$ of these pathogenic bacteria. The dissociated OAs appear to be consistently able to inhibit bacteria over a concentration range from $12.45 \mathrm{mM}$ to 21.05 $\mathrm{mM}$ dissociated OAs.

Alternatively, we also can consider the $\mathrm{pH}$ observed and the concentrations of dissociated OA levels at the MICs. Here we observed that the $\mathrm{pH}$ varied widely over the $S$. aureus MICs for both citric and L-lactic acid, with $\mathrm{pH}$ values of from 3.04 to 7.19 , respectively, and dissociated OA concentrations of 39.21 $\mathrm{mM}$ for citric and $63.55 \mathrm{mM}$ for L-lactic acid to inhibit all strains. Again, these two OAs are utilized by $S$. aureus which causes high levels of these two OAs required to inhibit all 164 strains tested. But a value of only $21.05 \mathrm{mM}$ dissociated acetic acid inhibited $100 \%$ of all 164 strains tested by the other four OAs. Three of the OAs, acetic, butyric and formic acid also inhibited these same 164 strains at the $21.05 \mathrm{mM}$ level. Acetic, butyric, formic and propionic acid inhibited 164 strains of $S$. aureus between the $\mathrm{pH}$ of 4.4 and 4.94, and between concentrations of dissociated OAs of 14.94 and $21.05 \mathrm{mM}$. Consistent and efficient inhibition of $S$. aureus strains was observed in our studies by the four dissociated non-utilized 
OAs at a maximum concentration of $21.05 \mathrm{mM}$.

We observed moderately high levels of citric and L-lactic acid that were required to inhibit $S$. aureus compared to the other four OAs tested. Identification of $S$. aureus by a biochemical test demonstrated that citrate is utilized by the bacterium [90]. The coagulation of plasma by $S$. aureus was shown to be caused by the utilization of citrate by the bacterium [91]. Multiple transport systems have evolved in $S$. aureus to assure the supply of iron from host sources [92]. Citrate is utilized by $S$. aureus in the production of two iron siderophores, staphyloferrin A (SA) and staphyloferrin B (SB) $[93,94]$. SA contains two molecules of citrate [95, 96], and SB contains a single molecule of citrate [97]. S. aureus can efficiently utilize L-lactate for growth [98-101]. L-Lactate can be effectively converted by $S$. aureus to acetate, and $S$. aureus can simultaneously use both L-lactate and glucose for growth [99]. When glucose becomes limiting, $S$. aureus can maintain exponential growth by switching to total aerobic utilization of L-lactate [99].

Studies aimed at comparing the potency of acetic and citric acid against a $S$. aureus contaminated mayonnaise-based salad demonstrated that acetic acid was more effective at inhibiting S. aureus than citric acid [102]. Also, a challenge test study to determine the combination of chemical preservatives and acidification that would be best for storage of orange fleshed sweet potato puree found that citric acid by itself was much poorer to use as a preservative than a combination of chemicals [103]. Therefore, based on our studies and the literature we disagree with the authors of a paper that suggested that "citric acid offers a novel prophylactic approach for controlling MRSA and VISA infections of wounds from orthopaedic patients" [104], and conclude that citric acid should definitely not be used to treat patients with $S$. aureus infections.

In order for S. aureus to infect areas of the human body it must counter act host innate immunity molecules [105], and the nitric oxide $\left(\mathrm{NO}^{*}\right)$ radical is a common broad-spectrum antimicrobial toxic agent used by a host to remove pathogenic microorganisms $[98,106,107]$. S. aureus is resistant to the NO* radical [97, 101, 107], because on long term exposures to $\mathrm{NO}^{*}$ it will primarily utilize L-lactate [98]. When $S$. aureus encounters $\mathrm{NO}^{*}$ it shifts to a new metabolic state and excretes L-lactate [107]. Also, the main reason S. aureus is found in skin infections and in the nasal cavity is because human sweat can contain as much as $\sim 50 \mathrm{mM}$ L-lactate which aids in colonization [108]. Also, nasal secretions are known to contain large concentrations of L-lactate, and S. aureus is known to commonly colonize the nasal passages which provides $S$. aureus a comfortable environment [109, 110]. Toxic shock syndrome (TSS) is commonly caused by $S$. aureus infection, but rarely occurs and the details leading from colonization to infection are not clear [111]. Only a small proportion of $S$. aureus strains carry the $t s t$ gene that encodes for the TSS toxin-1, which is basically responsible for the syndrome [112]. Lactic acid bacteria commonly colonize the vagina as well as other areas of humans, and produce lactic acid [113]. Over about the last 20 years the use of lactic acid producing bacteria has emerged as a common probiotic for the vaginal ecosystem [114]. The practice of using a probiotic that produces lactic acid in hopes of removing $S$. aureus does not appear appropriate and may be a catalyst for the low number of cases of toxic shock syndrome that regularly appear [111].

Based upon the above information concomitant with our data, L-lactic acid producing bacteria should not be used in areas where $S$. aureus is known to colonize, and citric acid and L-lactic acid should not be used in OA carcass washes or meat sprays to remove bacteria if $S$. aureus is one of the bacterial contaminates of concern.

\section{Conclusions}

During these studies we observed an $8.2 \%$ MRSA intracellular contamination of the swine mandibular lymph node tissue, demonstrating that $S$. aureus strains had invaded the tissues and were not just surface contamination, and this tissue may be used in pork sausage production. The $\mathrm{pH}$ values observed at the $\mathrm{MIC}_{\mathrm{M}} \mathrm{s}$ demonstrated that $\mathrm{pH}$ is not consistent with bacterial inhibition. The wide range of concentration values associated with the undissociated OAs show the variability in the undissociated OA concentrations from high to very low concentrations, and these low concentrations are unlikely to inhibit $S$. aureus. The high concentrations of citric and L-lactic acid observed for inhibition of $S$. aureus are a result of the bacterium utilizing citrate and L-lactate for siderophore production and bacterial growth, respectively. The use of L-lactic acid for increased growth of $S$. aureus explains why the human skin and nasal cavities are good sites for colonization and infection by $S$. aureus, and lactic acid may influence the toxic shock syndrome. These two OAs, citric and L-lactic acid, would not be good candidates to use for OA carcass washes or for OA meat sprays for removing bacteria since these OAs would be expected to help revive $S$. aureus. Whereas, all $164 \mathrm{~S}$. aureus strains tested were inhibited by the non-utilized OAs at a concentration of 21.05 $\mathrm{mM}$ dissociated OAs. Therefore, in this study as well as in previous studies with other pathogenic bacteria, the dissociated OAs showed good inhibition properties against pathogenic bacteria. A dissociated OA concentration of approximately $21 \mathrm{mM}$ of acetic, butyric, formic, and propionic acid could potentially be used to remove $S$. aureus from contaminated carcasses, meats, and possibly other surfaces. At lower dissociated OA concentrations, S. aureus strains would be expected to escape inhibition. Of the six OAs tested in this study, acetic, butyric, formic, and propionic acid are the most efficient at inhibiting $S$. aureus.

\section{Acknowledgements}

Mention of trade names, proprietary products or specific equipment is solely for the purpose of providing specific information and does not constitute a guarantee, warranty or endorsement by the U.S. Department of Agriculture and does not imply its approval to the exclusion of other products that may be suitable. Additionally, the views expressed in this 
article are those of the authors and do not necessarily reflect the official policy of the U.S. Department of Agriculture or the U.S. Government.

The authors declare that they have no competing interests.

\section{References}

[1] Diekema DJ, Pfaller MA, Schmitz FJ, Smayevsky J, Bell J, Jones RN, Beach M and the SENTRY Participants Group (2001) Survey of infections due to Staphylococcus species: Frequency of occurrence and antimicrobial susceptibility of isolates collected in the United States, Canada, Latin America, Europe, and the Western Pacific region for the SENTRY Antimicrobial Surveillance Program, 1997-1999. Clin. Infect. Dis. 32 (Suppl. 2): S114-132. doi: $10.1086 / 320184$.

[2] Spahich NA, Vitko NP, Thurlow LR, Temple B and Richardson AR (2016) Staphylococcus aureus lactate- and malate-quinone oxidoreductases contribute to nitric oxide resistance and virulence. Mol. Microbiol. 100: 759-773. doi: 10.1111/mmi.13347.

[3] Kluytmans J, van Belkum A and Verbrugh H (1997) Nasal carriage of Staphylococcus aureus: Epidemiology, underlying mechanisms, and associated risks. Clin. Microbiol. Rev. 10: 505-520. doi: 10.1128/CMR.10.3. 505.

[4] Gould IM (2009) Antibiotics, skin and soft tissue infection and methicillin-resistant Staphylococcus aureus: Cause and effect. Int. J. Antimicrob. Agents 34 (Suppl. 1): S8-S11. doi: 10.1016/ S0924-8579(09)70542-4.

[5] Saïd-Salim B, Dunman PM, McAleese FM, Macapagal D, Murphy E, McNamara PJ, Arvidson S, Foster TJ, Projan SJ and Kreiswirth BN (2003) Global regulation of Staphylococcus aureus genes by Rot. J. Bacteriol. 185: 610-619. doi: 10.1128/JB.185.2.610-619.2003.

[6] Otero MC, Morelli L and Nader-Macías ME (2006) Probiotic properties of vaginal lactic acid bacteria to prevent metritis in cattle. Lett. Appl. Microbiol. 43: 91-97. doi: 10.1111/j.1472-765X.2006.01914.x.

[7] CDC (2020) Foodborne germs and illnesses. Available at: https://www.cdc.gov/foodsafety/foodborne-germs.html (Accessed on: 17 July 2020).

[8] National Center for Case Methicillin resistant Staphylococcus aureus (MRSA) (2020) Available at: https://sciencecases.lib. buffalo.edu/files/Supplemental/UploadFolder/skin_graft.pdf (Accessed on: 06 October 2020).

[9] Verstappen KM, Willems E, Fluit AC, Duim B, Martens M and Wagenaar JA (2017) Staphylococcus aureus nasal colonization differs among pig lineages and is associated with the presence of other staphylococcal species. Front. Vet. Sci. 4: 97. doi: 10.3389/fvets.2017.00097.

[10] Lassok B and Tenhagen B-A (2013) From pig to pork: Methicillin-resistant Staphylococcus aureus in the pork production chain. J. Food Prot. 76: 1095-1108. doi: 10.4315/ 0362-028XJFP-12-341.

[11] Leonard FC and Markey BK (2008) Meticillin-resistant Staphylococcus aureus in animals: A review. Vet. J. 175: 27-36. doi: 10.1016/j.tvj1.2006.11.008.
[12] Cuny C, Friedrich A, Kozytska S, Layer F, Nübel U, Ohlsen K, Strommenger B, Walther B, Wieler L and Witte W (2010) Emergence of methicillin-resistant Staphylococcus aureus (MRSA) in different animal species. Int. J. Med. Microbiol. 300: 109-117. doi: 10.1016/j.ijmm.2009.11.002.

[13] Weese JS (2010) Methicillin-resistant Staphylococcus aureus in animals. ILAR J. 51: 233-244. doi: 10.1093/ilar. 51.3.233.

[14] Nadimpalli M, Stewart JR, Pierce E, Pisanic N, Love DC, Hall D, Larsen J, Carroll KC, Tekle T, Perl TM, et al. (2016) Livestock-associated, antibiotic-resistant Staphylococcus aureus nasal carriage and recent skin and soft tissue infection among industrial hog operation workers. PLOS ONE 11: e0165713. doi: 10.1371/journal.pone0165713.

[15] Carrel M, Schweizer ML, Sarrazin MV, Smith TC and Perencevich EN (2014) Residential proximity to large numbers of swine in feeding operations is associated with increased risk of methicillin-resistant Staphylococcus aureus colonization at time of hospital admission in rural Iowa veterans. Infect. Control Hospital Epidemiol. 35: 190-192. doi: 10.1086/674860.

[16] Parisi A, Caruso M, Normanno G, Latorre L, Miccolupo A, Fraccalvieri R, Intini F, Manginelli T and Santagada G (2019) MRSA in swine, farmers and abattoir workers in Southern Italy. Food Microbiol. 82: 287-293. https://doi.org/10.1016/j. fm.2019.03.003.

[17] Cuny C, Wieler LH and Witte W (2015) Livestock-associated MRSA: The impact on humans. Antibiotics 4: 521-543. doi: 10.3390/antibiotics404521.

[18] Slifierz MJ, Friendship RM and Weese JS (2015) Methicillin-resistant Staphylococcus aureus in commercial swine herds is associated with disinfectant and zinc usage. Appl. Environ. Microbiol. 81: 2690-2695. doi: 10.1128/AEM.00036-15.

[19] Smith TC, Gebreyes WA, Abley MJ, Harper AL, Forshey BM, Male MJ, Martin HW, Molla BZ, Sreevatsan S, Thakur S, et al. (2013) Methicillin-resistant Staphylococcus aureus in pigs and farm workers on conventional and antibiotic-free swine farms in the USA. PLOS ONE 8: e63704. doi: 10.1371/journal. pone. 0063704 .

[20] Davis MF, Pisanic N, Rhodes SM, Brown A, Keller H, Nadimpalli M, Christ A, Ludwig S, Ordak C, Spicer K, et al. (2018) Occurrence of Staphylococcus aureus in swine and swine workplace environments on industrial and antibiotic-free hog operations in North Carolina, USA: A one health pilot study. Environ. Res. 163: 88-96. doi: 10.1016/j.envres.2017. 12.010 .

[21] Wardyn SE, Forshey BM, Farina SA, Kates AE, Nair R, Quick MK, Wu JY, Hanson BM, O'Malley SM, Shows HW, et al. (2015) Swine farming is a risk factor for infection with high prevalence of carriage of multidrug-resistant Staphylococcus aureus. Clin. Infect. Dis. 61: 59-66. doi: 10.1093/cid/civ234.

[22] Rinsky JL, Nadimpalli M, Wing S, Hall D, Baron D, Price LB, Larsen J, Stegger M, Stewart J and Heaney CD (2013) Livestock-associated methicillin and multidrug resistant Staphylococcus aureus is present among industrial, not antibiotic-free livestock operation workers in North Carolina. PLOS ONE 8: e67641. doi: 10.1371/journal.pone.0067641.

[23] Smith TC and Wardyn SE (2015) Human infections with Staphylococcus aureus CC398. Cur. Environ. Health Rpt. 2: 41-51. doi: 10.1007/s40572-014-0034-8. 
[24] Ye X, Fan Y, Wang X, Liu W, Yu H, Zhou J, Chen S and Yao Z (2016) Livestock-associated methicillin and multidrug resistant S. aureus in humans is associated with occupational pig contact, not pet contact. Sci Rep. 6: 19184. doi: 10.1038/ srep19184.

[25] Hatcher SM, Rhodes SM, Stewart JR, Silbergeld E, Pisanic N, Larsen J, Jiang S, Krosche A, Hall D, Carroll KC, et al. (2017) The prevalence of antibiotic-resistant Staphylococcus aureus nasal carriage among industrial hog operation workers, community residents, and children living in their households: North Carolina, USA. Environ. Health Perspect. 125: 560-569. doi: 10.1289/EHP35.

[26] Nehme B, Létourneau V, Forster RJ, Veillette M and Duchaine C (2008) Culture-independent approach of the bacterial bioaerosol diversity in the standard swine confinement buildings, and assessment of the seasonal effect. Environ. Microbiol. 10: 665-675. doi: 10.1111/j.1462-2920.2007.01489.x.

[27] Cole D, Todd L and Wing S (2000) Concentrated swine feeding operations and public health: A review of occupational and community health effects. Environ. Health Perspect. 108: 685699. doi: 10.1289/ehp. 00108685.

[28] Beresin GA, Wright JM, Rice GE and Jagai JS (2017) Swine exposure and methicillin-resistant Staphylococcus aureus infection among hospitalized patients with skin and soft tissue infections in Illinois: A ZIP code-level analysis. Environ. Res. 159: 46-60. doi: 10.1016/j.envres.2017.07.037.

[29] Gibbs SG, Green CF, Tarwater PM, Mota LC, Mena KD and Scarpino PV (2006) Isolation of antibiotic-resistant bacteria from the air plume downwind of a swine confined or concentrated animal feeding operation. Environ. Health Perspect. 114: 1032-1037. doi: 10.1289/ehp.8910.

[30] Schulz J, Friese A, Klees S, Tenhagen BA, Fetsch A, Rösler U and Hartung $J$ (2012) Longitudinal study of the contamination of air and of soil surfaces in the vicinity of pig barns by livestock-associated methicillin-resistant Staphylococcus aureus. Appl. Environ. Microbiol. 78, 5666-5671. doi: 10.1128/AEM.00550-12.

[31] Chee-Sanford JC, Mackie RI, Koike S, Krapac IG, Lin Y-F, Yannarell AC, Maxwell S and Aminov RI (2009) Fate and transport of antibiotic residues and antibiotic resistance genes following land application of manure waste. J. Environ. Qual. 38, 1086-1108. doi: 10.2134/jeq2008.0128.

[32] Heuer H, Schmitt H and Smalla K (2011) Antibiotic resistance gene spread due to manure application on agricultural fields. Curr. Opin. Microbiol. 14, 236-243. doi: 10.1016/j.mib.2011.04.009.

[33] Casey JA, Curriero FC, Cosgrove SE, Nachman KE and Schwartz BS (2013) High-density livestock operations, crop field application of manure, and risk of community-associated methicillin-resistant Staphylococcus aureus infection in Pennsylvania. JAMA Intern. Med. 173: 1980-1990. doi: 10. 1001/jamainternmed.2013.10408.

[34] Pu S, Han F and Ge B (2009) Isolation and characterization of methicillin-resistant Staphylococcus aureus strains from Louisiana retail meats. Appl. Environ. Microbiol. 75, 265-267. doi: 10.1128/AEM.01110-08.

[35] O'Brien AM, Hanson BM, Farina SA, Wu JY, Simmering JE, Wardyn SE, Forshey BM, Kulick ME, Wallinga DB, Smith TC (2012) MRSA in conventional and alternative retail pork products. PLoS ONE, 7: e30092. doi: 10.1371/journal.pone. 0030092.
[36] Kluytmans J, van Leeuwen W, Goessens W, Hollis R, Messer S, Herwaldt L, Bruining H, Heck M, Rost J, van Leeuwen N, et al. (1995) Food-initiated outbreak of methicillin-resistant Staphylococcus aureus analyzed by pheno- and genotyping. $J$. Clin. Microbiol. 33: 1121-1128. PMCID: PMC228116, PMID: 7615715 .

[37] Jones TF, Kellum ME, Porter SS, Bell M and Schaffner W (2002) An outbreak of community-acquired foodborne illness caused by methicillin-resistant Staphylococcus aureus. Emerg. Infect. Dis. 8: 82-84. doi: 10.3201/eid0801.010174.

[38] Buchanan RL (1997) Identifying and controlling emerging foodborne pathogens: Research needs. Emerg. Infect. Dis. 3: 517-521. doi: 10.3201/eid0304.970416.

[39] Wachsmuth IK, Sparling PH, Barrett TJ and Potter ME (1997) Enterohemorrhagic Escherichia coli in the United States. FEMS Immunol. Med. Microbiol. 18: 233-239. doi: 10.1111/j. 1574-695X.1997.tb01051.x.

[40] Hinton MH and Corry JEL (1999) The decontamination of carcass meat. In: Poultry Meat Science, Richardson RI and Mead GC (Eds), Wallingford; Oxford, UK, CAB1 Publishing, pp. 285-295.

[41] Raftari M, Jalilian FA, Abdulamir AS, Son R, Sekawi Z and Fatimah AB (2009) Effect of organic acids on Escherichia coli O157:H7 and Staphylococcus aureus contaminated meat. Microbiol J. 3: 121-127. doi: 10.2174/18742858009030101 21.

[42] Raftari M, Aziz Jalilian F, Abdulamir AS, Ghafurian S, Radu S, Sekawi Z and Abu Bakar F (2011) Optimized antibacterial measures against Escherichia coli O157:H7 and Staphylococcus aureus. Afr. J. Microbiol. Res. 5: 3113-3121. doi: 10.5897/AJMR10.099.

[43] Mani-López E, Garci HS and López-Malo A (2012) Organic acids as antimicrobials to control Salmonella in meat and poultry products. Food Res. Int. 45: 713-721. doi: 10.1016/j. foodres.2011.04.043.

[44] Epling LK, Carpenter JA and Blankenship LC (1993) Prevalence of Campylobacter spp. and Salmonella spp. on pork carcasses and the reduction effected by spraying with lactic acid. J. Food Prot. 56, 536-537. doi: 10.4315/0362-028X-56.6.536.

[45] Castillo A, Lucia LM, Roberson DB, Stevenson TH, Mercado I and Acuff GR (2001) Lactic acid sprays reduce bacterial pathogens on cold beef carcass surfaces and in subsequently produced ground beef. J. Food Prot. 64: 58-62. doi: 10.4315/ 0362-028X-64.1.58.

[46] Departments of Pennsylvania State University, Texas Tech University, and Washington State University (2005) Antimicrobial spray treatments for red meat carcasses processed in very small meat establishments. Available http://meathaccp.wisc.edu/validation/assets/acid_spray_intervention booklet_from_penn_state_2005.pdf (Accessed on: 22 July 2020).

[47] Reynolds AE Jr (2005) Utilization of spray wash with organic acids (peroxyacetic acid and lactic acid) and chlorinated wash in combination, utilizing direct application methods, for pathogen reduction on pork and beef carcasses in small and very small meat processing plants (revised 8/24/2005). Available at: http://www.fsis.usda.gov/wps/wcm/connect/acc8bddb-eb64-4e a2-82eb-565cf337691a/New_Technology_C29_Summary_FY 2003.pdf?MOD=AJPERES (Accessed on: 22 July 2020). 
[48] Dickson JS, Hardin MD and Acuff GR (1996) Organic acid rinses. In: Microbiology Intervention Methods, Proceedings of the $49^{\text {th }}$ Annual Reciprocal Meat Conference, American Meat Science Association, pp. 129-131. Available at: https://meatscience.org/docs/default-source/publications-resou $\mathrm{rces} / \mathrm{rmc} / 1996 /$ organic-acid-rinses.pdf?sfvrsn=2 (Accessed on: 18 September 2020).

[49] Dickson JS and Acuff GR (2017) Maintaining the safety and quality of beef carcass meat. In: Ensuring Safety and Quality in the Production of Beef. Vol. 1: Safety. Acuff, G. R.; Dickson, J. S. (Eds.), Burleigh Dodds Science Publishing: Sawston, Cambridge, UK. Available at: https://lib.dr.iastate.edu/cgi/viewcontent.cgi?article $=1354 \&$ co ntext=ans_pubs (Accessed on: 22 July 2020).

[50] Ricke SC (2003) Perspectives on the use of organic acids and short chain fatty acids as antimicrobials. Poult. Sci. 82: 632639. doi: $10.1093 / \mathrm{ps} / 82.4 .632$.

[51] Minor TE and Marth EH (1970) Growth of Staphylococcus aureus in acidified pasteurized milk. J. Milk Food Technol. 33: 516-520. doi: 10.4315/0022-2747-33.11.516.

[52] Sofos JN and Busta FF (1981) Antimicrobial activity of sorbate J. Food Prot. 44: 614-622. doi: 10.4315/0362-028X-44.8.614.

[53] Blocher JC, Busta FF and Sofos JN (1982) Influence of potassium sorbate and $\mathrm{pH}$ on ten strains of type A and B Clostridium botulinum. J. Food Sci. 47: 2028-2032. doi: 10.1111/j.1365-2621.1982.tb12938.x.

[54] Ray B and Sandine WE (1992) Acetic, propionic, and lactic acids of starter culture bacteria as biopreservatives. In Food Biopreservatives of Microbial Origin; Ray, B., Daeschel, M., Eds.; CRC Press, Inc.; Boca Raton, FL, USA, pp. 103-136.

[55] Breidt F Jr, Hayes JS and McFeeters RF (2004) Independent effects of acetic acid and $\mathrm{pH}$ on survival of Escherichia coli in simulated acidified pickle products. J. Food Prot. 67: 12-18. doi: $10.4315 / 0362-028 \mathrm{x}-67.1 .12$.

[56] Leeson S (2007) Balancing science versus societal issues in poultry nutrition. CAB Rev. Perspect. Agric. Vet. Sci. Nutr. Nat. Resour. 2: 071. doi: 10.1079/PAVSNNR20072071.

[57] Ghosh HK, Halder G, Samanta G and Koley S (2008) Effect of dietary supplementation of organic acid and mannan oligosaccharide on the plasma minerals and carcass traits of Japanese quail (Coturnix coturnix japonica). Res. J. Vet. Sci. 1: 44-49. doi: 10.3923/rjvs.2008.44.49.

[58] Van Deun K, Haesebrouch F, Van Immerseel F, Ducatelle R and Pasmans F (2008) Short-chain fatty acids and L-lactate as feed additives to control Campylobacter jejuni infections in broilers. Avian Pathol. 37: 379-383. doi: 10.1080/03079450802216603.

[59] Bushell FML, Tonner PD, Jabbari S, Schmid, AK and Lund PA (2019) Synergistic impacts of organic acids and $\mathrm{pH}$ on growth of Pseudomonas aeruginosa: A comparison of parametric and Bayesian non-parametric methods to model growth. Front. Microbiol. 9: 3196. doi: 10.3389/fmicb.2018. 03196.

[60] Presser KA, Ross T and Ratkowsky DA (1998) Modelling the growth limits (growth/no growth interface) of Escherichia coli as a function of temperature, $\mathrm{pH}$, lactic acid concentration, and water activity. Appl. Environ. Microbiol. 64: 1773-1779. PMCID: PMC106229; PMID: 9572950.
[61] Carpenter CE and Broadbent JR (2009) External concentration of organic acid anions and $\mathrm{pH}$ : Key independent variables for studying how organic acids inhibit growth of bacteria in mildly acidic foods. J. Food Sci. 74: R12-R15. doi: 10.1111/j.1750-3841.2008.00994.x.

[62] Beier RC, Harvey RB, Hernandez CA, Hume ME, Andrews K, Droleskey RE, Davidson MK, Bodeis-Jones S, Young S, Duke SE, et al. (2018) Interactions of organic acids with Campylobacter coli from swine. PLoS ONE 13: e0202100. doi: 10.1371/journal.pone.0202100.

[63] Beier RC, Poole TL, Brichta-Harhay DM, Anderson RC, Bischoff KM, Hernandez CA, Bono JL, Arthur TM, Nagaraja TG, Crippen TL, et al. (2013) Disinfectant and antibiotic susceptibility profiles of Escherichia coli $\mathrm{O} 157: \mathrm{H} 7$ strains from cattle carcasses, feces, and hides and ground beef from the United States. J. Food Prot. 76: 6-17. doi: 10.4315/0362-028X.JFP-12-253.

[64] Beier RC, Foley SL, Davidson MK, White DG, McDermott PF, Bodeis-Jones S, Zhao S, Andrews K, Crippen TL, Sheffield CL, et al. (2014) Characterization of antibiotic and disinfectant susceptibility profiles among Pseudomonas aeruginosa veterinary isolates recovered during 1994-2003. J. Appl. Microbiol. 118: 326-342. doi: 10.1111/jam.12707.

[65] Beier RC, Franz E, Bono JL, Mandrell RE, Fratamico PM, Callaway TR, Andrews K, Poole TL, Crippen TL, Sheffield CL, et al. (2016) Disinfectant and antimicrobial susceptibility profiles of the big six non-O157 Shiga toxin-producing Escherichia coli strains from food animals and humans. $J$. Food Prot. 79: 1355-1370. doi: 10.4315/0362-028X.JFP-15-600.

[66] Beier RC, Callaway TR, Andrews K, Poole TL, Crippen TL, Anderson RC and Nisbet DJ (2017) Interactions of organic acids with Salmonella strains from feedlot water-sprinkled cattle. J. Food Chem. Nanotechnol. 3: 60-66. doi: 10.17756/ jfen.2017-038.

[67] Beier RC, Byrd JA, Caldwell D, Andrews K, Crippen TL, Anderson RC and Nisbet DJ (2019) Inhibition and interactions of Campylobacter jejuni from broiler chicken houses with organic acids. Microorganisms 7: 223 . doi: 10.3390/microorganisms 7080223 .

[68] Beier RC, Harvey RB, Poole TL, Hume ME, Crippen TL, Highfield LD, Alali WQ, Andrews K, Anderson RC and Nisbet DJ (2018) Interactions of organic acids with vancomyin-resistant Enterococcus faecium isolated from community wastewater in Texas. Appl. Microbiol. 126: 480 488. doi: 10.1111/jam.14145.

[69] Alakomi H-L, Skyttä E, Saarela M, Mattila-Sandholm T, Latva-Kala K and Helander IM (2000) Lactic acid permeabilizes Gram-negative bacteria by disrupting the outer membrane. Appl. Environ. Microbiol. 66: 2001-2005. doi: 10.1128/AEM.66.5.2001-2005.2000.

[70] Dallenne C, Da Costa A, Decré D, Favier C and Arlet G (2010) Development of a set of multiplex PCR assays for the detection of genes encoding important $\beta$-lactamases in Enterobacteriaceae. J. Antimicrob. Chemother. 65: 490-495. doi: $10.1093 / \mathrm{jac} / \mathrm{dkp} 498$.

[71] Mason WJ, Blevins JS, Beenken K, Wibowo N, Ojha N and Smeltzer MS (2001) Multiplex PCR protocol for the diagnosis of staphylococcal infection. J. Clin. Microbiol. 39: 3332-3338. doi: 10.1128/JCM.39.3332-3338.2001. 
[72] Clinical and Laboratory Standards Institute (CLSI) (2018) Methods for dilution antimicrobial susceptibility tests for bacteria that grow aerobically, $11^{\text {th }}$ ed. CLSI approved standard, M07. Clinical and Laboratory Standards Institute, Wayne, PA, USA.

[73] Andrews JM (2001) Determination of minimum inhibitory concentrations. J. Antimicrob. Chemother. 48 (Suppl. S1): 516. doi: 10.1093/jac/48.suppl_1.5.

[74] Helmenstine AM (2019) Henderson-Hasselbalch equation and example. Available at: http://chemistry.about.com/od/ acidsbase 1/a/hendersonhasselbalch.htm (Accessed on: 4 August 2020).

[75] Gill CO and Bryant J (1992) The contamination of pork with spoilage bacteria during commercial dressing, chilling and cutting of pig carcasses. Int. J. Food Microbiol. 16: 51-62. doi: 10.1016/0168-1605(92)90125-M

[76] Sörqvist S and Danielsson Tham M-L (1987) Bacterial contamination of the scalding water during vat scalding of pigs. Fleischwirtschaft Int. 2: 39-43. URN: urn:nbn:se:oru-58128.

[77] Gill CO, McGinnis DS, Bryant J and Chabot B (1995) Decontamination of commercial polished pig carcasses with hot water. Food Microbiol. 12: 337-344. doi: 10.1016/S0740-0020(95)80090-5.

[78] Beneke B, Klees S, Stührenberg B, Fetsch A and Kraushaar B Tenhagen B-A (2011) Prevalence of methicillin-resistant Staphylococcus aureus in a fresh meat pork production chain. $J$ Food Prot. 74: 126-129. doi: 10.4315/0362-028X.JFP-10-250.

[79] Shaheen BW, Miller ME and Oyarzabal OA (2007) In vitro survival at low $\mathrm{pH}$ and acid adaptation response of Campylobacter jejuni and Campylobacter coli. J. Food Saf. 27: 326-343. doi: 10.1111/j.1745-4565.2007. 00083.x.

[80] Mann E, Dzieciol M, Pinior B, Neubauer V, Metzler-Zebeli BU, Wagner M, AND Schmitz-Esser S (2015) High diversity of viable bacteria isolates from lymph nodes of slaughtered pigs and its possible impacts for food safety. J. Appl. Microbiol. 119: 1420-1432. doi: 10.1111/jam.12933.

[81] Chaves BD, Ruiz H, Garcia LG, Echeverry A, Thompson L, Miller MF and Brashears MM (2017) High prevalence of Salmonella in lymph nodes and tonsils of swine presented for slaughter in Mexico. Food Prot. Trends 37: 25-28.

[82] Castagna SMF, Schwarz P, Canal CW and Cardoso M (2004) Presence of Salmonella in the intestinal tract and tonsils/mandibular lymph nodes in pigs at slaughter. Arq. Bras. Med. Vet. Zootec. 56: 300-306. (In Portuguese) doi: $10.1590 / \mathrm{S} 0102-09352004000300003$.

[83] Gahan CG, O'Driscoll B and Hill C (1996) Acid adaptation of Listeria monocytogenes can enhance survival in acidic foods and during milk fermentation. Appl. Environ. Microbiol. 62: 3128-3132. doi: 10.1128/AEM.62.9.3128-3132.1996.

[84] Castanie-Cornet M-P, Penfound TA, Smith D, Elliott JF and Foster JW (1999) Control of acid resistance in Escherichia coli. J. Bacteriol. 181: 3525-3535. PMCID: PMC93821, PMID: 10348866.

[85] Varsaki A, Murphy C, Barczynska A, Jordan K and Carroll C (2015) The acid adaptive tolerance response in Campylobacter jejuni induces a global response, as suggested by proteomics and microarrays. Microb. Biotechnol. 8: 974-988. doi: 10.1111/1751-7915.12302.
[86] Smittle RB (2000) Microbiological safety of mayonnaise, salad dressings, and sauces produced in the United States: A review. J. Food Prot. 63: 1144-1153. doi: 10.4315/0362-028X-63.8.1144.

[87] McKellar RC and Knight KP (1999) Growth and survival of various strains of enterohemorrhagic Escherichia coli in hydrochloric and acetic acid. J. Food Prot. 62: 1466-1469. doi: 10.4315/0362-028x-62.12.1466.

[88] Blocker JC and Busta FF (1981) Antimicrobial activity of sorbate. J. Food Protect. 44: 614-622. doi: 10.4315/ 0362-028X-44.8.614.

[89] Hirshfield IN, Terzulli S and O'Byrne C (2003) Weak organic acids: A panoply of effects on bacteria. Sci. Prog. 86: 245-269. doi: $10.3184 / 003685003783238626$.

[90] Aryal S (2020) Biochemical test of Staphylococcus aureus. Available at: https://microbenotes.com/biochemical-test-of-staphylococcusaureus/ (Accessed on: 20 August 2020).

[91] Bayliss BG and Hall ER (1965) Plasma coagulation by organisms other than Staphylococcus aureus. J. Bacteriol. 89: 101-105. PMID: 14255647; PMCID: PMC315554.

[92] Hammer ND and Skaar EP (2011) Molecular mechanisms of Staphylococcus aureus iron acquisition. Annu. Rev. Microbiol. 65: 129-147. doi: 10.1146/annurev-micro-090110-102851.

[93] Kobylarz MJ, Grigg JC, Sheldon JR, Heinrichs DE and Murphy MEP (2014) SbnG, a citrate synthase in Staphylococcus aureus: A new fold on an old enzyme. J. Biol. Chem. 289: 33797-33807. doi: 10.1074/jbc.M114.603175; PMCID: PMC4256314.

[94] Sheldon JR, Marolda CL and Heinrichs DE (2014) TCA cycle activity in Staphylococcus aureus is essential for iron-regulated syntheses of staphyloferrin A, but not staphyloferrin B: The benefit of a second citrate synthase. Mol. Microbiol. 92: 824 839. doi: $10.1111 / \mathrm{mmi} .12593$.

[95] Beasley FC, Vinés ED, Grigg JC, Zheng Q, Liu S, Lajoie GA, Murphy MEP and Heinrichs DE (2009) Characterization of staphyloferrin A biosynthetic and transport mutants in Staphylococcus aureus. Mol. Microbiol. 72: 947-963. doi: 10.1111/j.1365-2958.2009.06698.x.

[96] Cotton JL, Tao J and Balibar CJ (2009) Identification and characterization of the Staphylococcus aureus gene cluster coding for staphyloferrin A. Biochemistry 48: 1025-1035. doi: 10.1021/bi801844c.

[97] Cheung J, Beasley FC, Liu S, Lajoie GA and Heinrichs DE (2009) Molecular characterization of staphyloferrin B biosynthesis in Staphylococcus aureus. Mol. Microbiol. 74: 594-608. doi: 10.1111/j.1365-2958.2009.06880.x.

[98] Fuller JR, Vitko NP, Perkowski EF, Scott E, Khatri D, Spontak JS, Thurlow LR and Richardson AR (2011) Identification of a lactate-quinone oxidoreductase in Staphylococcus aureus that is essential for virulence. Front. Cell. Infect. Microbiol. 1: 19. doi: $10.3389 /$ fcimb.2011.00019.

[99] Ferreira MT, Manso AS, Gaspar P, Pinho MG and Neves AR (2013) Effect of oxygen on glucose metabolism: Utilization of lactate in Staphylococcus aureus as revealed by in vivo NMR studies. PLOS ONE 8: e58277. doi: 10.1371/journal.pone. 0058277 . 
[100] Hara T, Matsui H and Shimizu H (2014) Suppression of microbial metabolic pathways inhibits the generation of the human body odor component diacetyl by Staphylococcus spp. PLOS ONE 9: e111833. doi: 10:1371/ journal.pone.0111833.

[101] Jiang T, Gao C, Ma C and Xu P (2014) Microbial lactate utilization: Enzymes, pathogenesis, and regulation. Trends Microbiol. 22: 589-599. doi: 10.1016/j.tim.2014.05.008.

[102] Bornemeier V, Peters D and Albrecht JA (1997) Effect of added citric acid and acetic acid on the growth of Staphylococcus and Listeria in mayonnaise-based salad. J. Am. Dietet. Assoc. 97 (Suppl.): A-83. doi: 10.1016/S0002-8223(97)00610-X.

[103] Musyoka JN, Abong GO, Mbogo DM, Fuchs R, Low J, Heck S and Muzhingi $\mathrm{T}$ (2018) Effects of acidification and preservatives on microbial growth during storage of orange fleshed sweet potato puree. Int. J. Food Sci. 8410747. https://doi.org/10.1155/2018/8410747.

[104] Thool, V. U.; Wadher, B. J.; Bhoosereddy, G. L. Citric acid: A prospective permeabilizer for treatment of VISA infections. Int. J. Curr. Microbiol. Ap. Sci. 2014, 3, 177-183. https://www.ijcmas.com/vol-3-9/V.\%20U.Thool,\%20et\%20al. pdf.

[105] Foster, T. J. Immune evasion by staphylococci. Nat. Rev. Microbiol. 2005, 3, 948-958. doi: 10.1038/nrmicro1289.

[106] DeGroote, M. A.; Fang, F. C. Antimicrobial properties of nitric oxide. In Nitric Oxide and Infection, Vol. 1, Fang, F. C., Ed.; Springer; Boston, MA, USA, 1999; pp. 231-247. doi: 10.1007/0-306-46816-6 12.

[107] Richardson, A. R.; Libby, S. J.; Fang, F. C. A nitric oxide-inducible lactate dehydrogenase enables Staphylococcus aureus to resist innate immunity. Science 2008, 319 (5870), 1672-1676. doi: 10.1126/science. 1155207.
[108] Sakharov DA, Shkurnifov MU, Vagin M Yu, Yashina EI, Karyakin AA and Tonevitsky AG (2010) Relationship between lactate concentrations in active muscle sweat and whole blood. Bull. Exp. Biol. Med. 150: 83-85. doi: 10.1007/s10517-010-1075-0.

[109] Stierna P, Söderlund K and Hultman E (1991) Chronic maxillary sinusitis. Energy metabolism in sinus mucosa and secretion. Acta Otolaryngol. 111: 135-143. doi: 10.3109/ 00016489109137364.

[110] Westrin KM, Stierna P, Söderlund K and Carlsöö B (1992) Lactic acid isomers and fatty acids in sinus secretion: A longitudinal study of bacterial and leukocyte metabolism in experimental sinusitis. Scand. J. Infect. Dis. 24: 765-772. doi: $10.3109 / 00365549209062462$.

[111] Silversides JA, Lappin E and Ferguson AJ (2010) Staphylococcal toxic shock syndrome: Mechanisms and management. Curr. Infect. Dis. Rep. 12: 392-400. doi: 10.1007/s11908-010-0119-y.

[112] Schlebusch S, Schooneveldt JM, Huygens F and Nimmo GR (2009) Prevalence of Staphylococcus aurous strains in an Australian cohort, 1989-2003: Evidence for the low prevalence of the toxic shock toxin and Panton-Valentine leucocidin genes. Eur. J. Clin. Microbiol. Infect. Dis. 28: 1183-1189. doi: 10.1007/s10096-009-0761-1.

[113] Charlier C, Cretenet M, Even S and Le Loir Y (2009) Interactins between Staphylococcus aureus and lactic acid bacteria: An old story with new perspectives. Int. J. Food Microbiol. 131: 30-39. doi: 10.1016/j.ijfoodmicro.2008.06. 032 .

[114] Reid G and Bruce AW (2003) Urogenital infections in women: Can probiotics help? Postgrad. Med. J. 79: 428-432. doi: 10.1136/pmj.79.934.428. 